Marquette University

e-Publications@Marquette

$2-1-2013$

Generation of Molecular Complexity from Cyclooctatetraene: Preparation of Optically Active Protected Aminocycloheptitols and Bicyclo[4.4.1] undecatriene

Mohamed F. El-Mansy

Marquette University

Anobick Sar

Marquette University

Sergey Lindeman

Marquette University, sergey.lindeman@marquette.edu

William Donaldson

Marquette University, william.donaldson@marquette.edu

Accepted version. Chemistry, a European Journal, Vol. 19, No. 7 (February 2013): 2330-2336. DOI. (C) 2013 Wiley-VCH Verlag 2013. Used with permission

The spectral data used in the research for this article may be found here. 


\title{
Generation of molecular complexity from cyclooctatetraene: preparation of optically active protected aminocycloheptitols and bicyclo[4.4.1] undecatriene
}

\author{
Mohamed F. El-Mansy \\ Department of Chemistry, Marquette University \\ Milwaukee, WI \\ Anobick Sar \\ Department of Chemistry, Marquette University \\ Milwaukee, WI \\ Sergy Lindeman \\ Department of Chemistry, Marquette University \\ Milwaukee, WI \\ William A. Donaldson*a \\ Department of Chemistry, Marquette University \\ Milwaukee, WI
}

\begin{abstract}
The racemic (6-cyclo-heptadienyl) $\mathrm{Fe}(\mathrm{CO}) 3_{3}{ }^{+}$cation $(( \pm)-7)$, prepared from cyclooctatetraene, was treated with a variety of carbon and heteroatom nucleophiles. Attack took place at the less hindered $\mathrm{C}^{1}$ dienyl carbon and decomplexation of the (cycloheptadiene) $\mathrm{Fe}(\mathrm{CO})_{3}$ complexes gave products rich in functionality for further synthetic manipulation. In particular, a seven-step route was developed from
\end{abstract}


racemic (6-styryl-2,4-cycloheptadien-1-yl)phthalimide $(( \pm)-9 d)$ to afford the optically active aminocycloheptitols $(-)-\mathbf{2 0}$ and $(+)-\mathbf{2 0}$. Keywords: cyclitols, hydrocarbons, pi complexes, regioselectivity, synthetic methods

\section{Introduction}

The use of simple hydrocarbons as starting materials for the synthesis of complex molecules relies on efficient methods for oxidation, functionalization, or rearrangement. For example, various researchers have explored cyclopentadiene ${ }^{[1]}$ or cycloheptatriene ${ }^{[2]}$ as precursors for the preparation of a wide variety of drug candidates, natural products, and synthetic products. The simple hydrocarbon cyclooctatetraene (COT), prepared by the catalytic tetramerization of acetylene, ${ }^{[3]}$ has recently been used in the syntheses of minocyclitols, ${ }^{[4 a]}$ bis-homoconduritols, ${ }^{[4 b]}$ bis-homoinositol, ${ }^{[4 c]}$ pentacycloanammoxic acid methyl ester, ${ }^{[4 \mathrm{~d}]}$ the polyene segment of roxaticin, ${ }^{[4 \mathrm{e}]}$ and cyclooctitols. $\left.{ }^{[4 \mathrm{f}}\right]$ Tricarbonyl(cyclooctatetraene) iron $(\mathbf{1})$, which is readily prepared from COT, ${ }^{[5]}$ reacts with a variety of electrophiles to form (dienyl)iron cations. ${ }^{[6]}$ We have previously reported on the synthesis of 2-(2'-carboxycycloalkyl)glycines ( $\mathbf{2}$ and $\mathbf{3}$, Scheme 1) from cations derived from 1. ${ }^{[7]}$

Polyhydroxyl aminocyclohexanes ("aminocyclitols") and its derivatives are important biological entities. For example, certain 5amino-1,2,3,4-cyclohexanetetraols are inhibitors of $\alpha$-glucosidase and $\alpha$-galactosidase. ${ }^{[8]}$ Although a variety of synthetic routes to aminocyclitols have been reported, ${ }^{[8]}$ there are considerably fewer syntheses of analogues with seven-membered-rings aminocycloheptitols, Figure 1). ${ }^{[9]}$ In general, these routes utilize chiral pool materials to generate the hydroxyl stereocenters. For example, Casiraghi and coworkers reported a 12-step synthesis of $\mathbf{4}$ that relied on a vinylogous aldol reaction between 2-(tert-butyldimethylsilyloxy) pyrole and D-arabinose bis-acetonide, ${ }^{[9 a]}$ and Yamada and co-workers prepared $\mathbf{5}$ from D-xylose by using an intramolecular nitrone-alkene cycloaddition. ${ }^{[9 c]}$ Similarly, the cycloheptane ring can be found in the unique bicyclic skeleton of ingenol (6). This diterpene has attracted considerable synthetic interest because various esters of ingenol act as activators of protein kinase (PKC). ${ }^{[10]}$ As part of our interest in the 
generation of molecular complexity from simple hydrocarbons, ${ }^{[7]}$ we herein report on the reactivity of the (6-styrylcycloheptadienyl) iron cation $\mathbf{7}$ and transformation of these products into optically active aminocycloheptitols and the bicyclo[4.4.1]undecatriene skeleton.

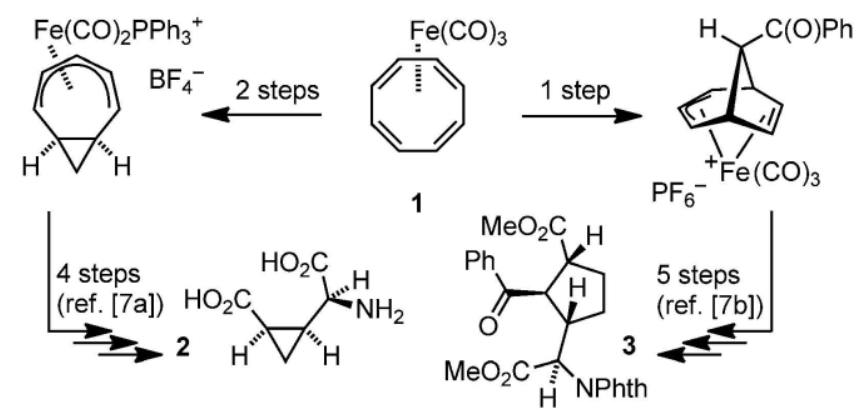

Scheme 1. Preparation of 2-(2'-carboxycycloalkyl)glycines from (COT)$\mathrm{Fe}(\mathrm{CO})_{3}$.
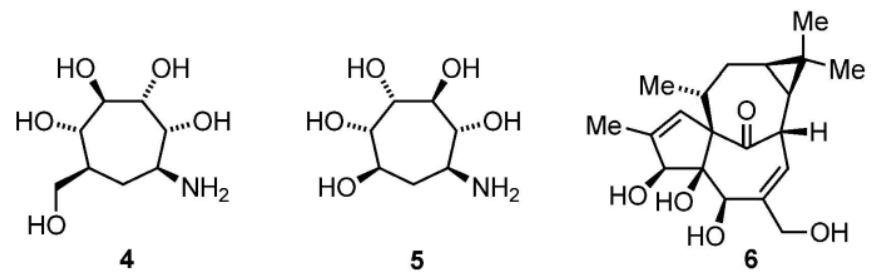

Figure 1. Structures of aminocycloheptitols and ingenol.

\section{Results and Discussion}

The literature procedure for the reaction of reaction of $\mathbf{1}$ with tropylium tetrafluoroborate in the presence of pyridine is reported to give (7-styryl-1,3,5-cycloheptatriene)iron in modest yield (41\%). ${ }^{[6 d]}$ The mechanistic rationale proposed by Connelly et al. begins with addition of the electrophile to a noncoordinated olefin to generate a homobutyl cation (Scheme 2, A). Rearrangement of the homobutyl cation to a cyclopropylcarbinyl cation affords structure B, which undergoes a $[3,3]$-Cope rearrangement to generate the norcaradiene intermediate $\mathbf{C}$. Opening of both of the cyclopropane rings gives the cyclohexadienyl cation $\mathbf{D}$, which upon deprotonation gives the styrylcycloheptatriene complex. Protonation of this cycloheptatriene complex with $\mathrm{HBF}_{4}{ }^{+}$yields the cation $( \pm)-7(67 \%)$. We were able to 
improve the overall yield of $\mathbf{7}$ (76\% from $\mathbf{1}$ ) by i) using 1 equivalent of pyridine, ii) exhaustive extraction of the reaction mixture, and iii) use of the crude cycloheptatriene complex, without chromatographic purification, for protonation.

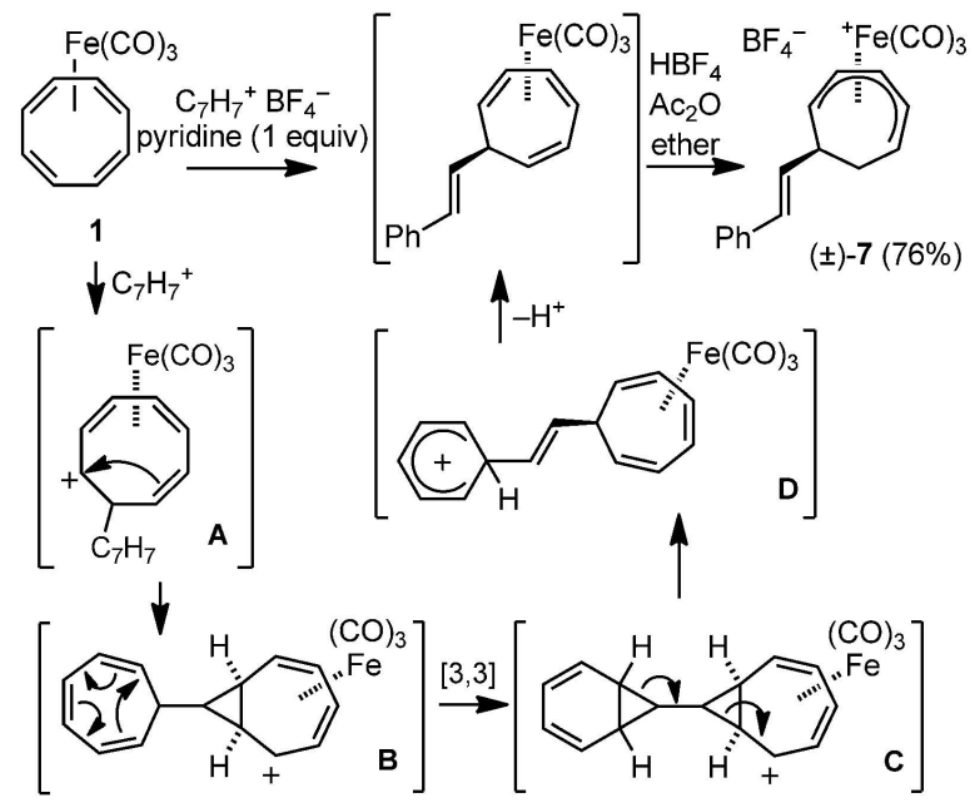

Scheme 2. Preparation of the (6-cycloheptadienyl) $\mathrm{Fe}(\mathrm{CO})_{3}{ }^{+}$cation and proposed mechanism for the formation of (7-styryl-1,3,5-cycloheptatrie$\mathrm{ne}) \mathrm{Fe}(\mathrm{CO})_{3}$.

The reaction of $\mathbf{7}$ with a variety of nucleophiles proceeded exclusively by attack at $\mathrm{C}^{1}$ to afford the cis-1-substituted-6-styryl-2,4heptadiene)iron complexes ( \pm )-8a-g (Scheme 3, Table 1). The structures of $\mathbf{8} \mathbf{a}-\mathbf{g}$ were assigned on the basis of their NMR spectral data. In particular, two signals at approximately $\delta=87-91 \mathrm{ppm}$ in the ${ }^{13} \mathrm{C}$ NMR spectra and multiplets integrating to two protons at approximately $\delta=4.9-5.6 \mathrm{ppm}$ in the ${ }^{1} \mathrm{H}$ NMR spectra are consistent with the two internal carbons $\left(\mathrm{C}^{3} / \mathrm{C}^{4}\right)$ of an $\eta^{4}$-bound cycloheptadiene and their attached protons. ${ }^{[11]}$ 


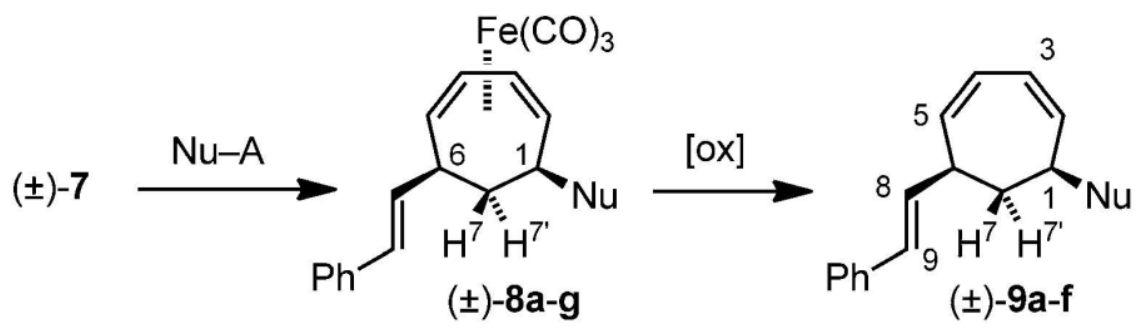

Scheme 3. Reaction of the (6-cycloheptadienyl) $\mathrm{Fe}(\mathrm{CO})_{3}{ }^{+}$cation with nucleophiles.

In addition, an apparent quartet at approximately $\delta=0.9-2.0 \mathrm{ppm}$ $(\mathrm{J} \approx 12 \mathrm{~Hz})$ in the ${ }^{1} \mathrm{H}$ NMR spectra for $( \pm)-\mathbf{8 a}, \mathbf{c}, \mathbf{d}$, and $\mathbf{f}$ was assigned to $\mathrm{H}^{7}$. The three large couplings are due to diaxial vicinal coupling of $\mathrm{H}^{7}$ with $\mathrm{H}^{1}$ and $\mathrm{H}^{6}$, and a geminal coupling to $\mathrm{H}^{7^{\prime}}$. The regioselectivity for nucleophilic addition to $\mathbf{7}$ is similar to that observed for other 6 substituted (heptadienyl)Fe $\mathrm{Fations.}^{[11]}$

Table 1. Nucleophilic addition to $( \pm)-\mathbf{7}$ and decomplexation of $( \pm)-\mathbf{8}$.

\begin{tabular}{|c|c|c|c|}
\hline $\mathrm{Nu}-\mathrm{A}$ & $\mathrm{Nu}$ & $\begin{array}{l}\text { Complex } \\
\text { ([\%]) }\end{array}$ & $\begin{array}{l}\text { free } \\
\text { diene } \\
([\%])^{[a]}\end{array}$ \\
\hline $\mathrm{LiCH}\left(\mathrm{CO}_{2} \mathrm{Me}\right)_{2}$ & $\mathrm{CH}\left(\mathrm{CO}_{2} \mathrm{Me}\right)_{2}$ & $8 \mathbf{a}(46)$ & - \\
\hline $\mathrm{LiC}($ allyl $)\left(\mathrm{CO}_{2} \mathrm{Me}\right)_{2}$ & $\mathrm{C}\left(\mathrm{CO}_{2} \mathrm{Me}\right)_{2}$ allyl & $8 \mathbf{b}(-)^{[b]}$ & $9 \mathbf{b}(67)^{[c]}$ \\
\hline $\mathrm{LiC}$ (propargyl $)\left(\mathrm{CO}_{2} \mathrm{Me}\right)_{2}$ & $\mathrm{C}$ (propargyl) $\left(\mathrm{CO}_{2} \mathrm{Me}\right)_{2}$ & $8 \mathbf{c}(-)^{[b]}$ & $9 \mathbf{c}(33)$ \\
\hline $\mathrm{K}^{+-} \mathrm{NPhth}$ & NPhth & 8d (72) & $\begin{array}{l}9 \mathbf{d}(88) \\
(81)^{[d]]}\end{array}$ \\
\hline $\mathrm{Na}^{+-} \mathrm{N}($ allyl $) \mathrm{SO}_{2}$ Tol & (allyl) $\mathrm{N}\left(\mathrm{SO}_{2} \mathrm{Tol}\right)$ & $8 \mathbf{e}(-)^{[\mathrm{ee}]}$ & $\mathbf{9 e}(51)^{[c]}$ \\
\hline $\mathrm{H}_{2} \mathrm{O} / \mathrm{K}_{2} \mathrm{CO}_{3}$ & $\mathrm{OH}$ & $\mathbf{8 f}(70)$ & $9 \mathbf{f}(50)^{[f]}$ \\
\hline $\mathrm{PPh}_{3}$ & $\mathrm{PPh}_{3}{ }^{+} \mathrm{BF}_{4}^{-}$ & $8 \mathbf{g}(83)$ & - \\
\hline
\end{tabular}

[a] Cerium ammonium nitrate (CAN) was used as the oxidant unless otherwise noted. [b] The product was an inseparable mixture of $\mathbf{8 c}$ and unreacted nucleophile. [c] Yield of $\mathbf{9 d}$ from $\mathbf{7}$ over two steps (nucleophilic addition/decomplexation). [d] Yield of $\mathbf{9 d}$ from $\mathbf{7}$ with only one chromatographic purification. [e] Product was not isolated but used in the decomplexation step. [f] $\mathrm{H}_{2} \mathrm{O}_{2} / \mathrm{NaOH}$ was used as the oxidant instead of CAN.

Oxidative decomplexation of $( \pm)-\mathbf{8 b}-\mathbf{e}$ with cerium ammonium nitrate (CAN) in methanol gave the corresponding free ligands permission has been granted for this version to appear in e-Publications@Marquette. Wiley-VCH Verlag does not grant permission for this article to be further copied/distributed or hosted elsewhere without the express permission from Wiley-VCH Verlag. 
$( \pm)-\mathbf{9 b}-\mathbf{e}$, respectively (Table 1 ). In contrast, successful decomplexation of cycloheptadienol complex $( \pm)-\mathbf{8} \mathbf{f}$ required the use of basic decomplexation conditions $\left(\mathrm{H}_{2} \mathrm{O}_{2} / \mathrm{NaOH} / \mathrm{MeOH}\right)$ to afford $( \pm)-\mathbf{9}$ f. The structures of the products $( \pm)-\mathbf{9 c}$, $\mathbf{d}$, and $\mathbf{f}$ were assigned based on their NMR spectral data. In particular, signals in the range of $\delta=5.5-6.0 \mathrm{ppm}$ that integrate to four protons correspond to the olefinic protons of the conjugated diene portion of the molecule. The structural assignment of $( \pm)$-9d was further corroborated by singlecrystal X-ray diffraction analysis. ${ }^{[12]}$

Treatment of $( \pm)-9 \mathbf{b}$ with the Grubbs 1st generation catalyst (G-I) led to the ring-closed product $( \pm)$-10 (Scheme 4$){ }^{[13]}$ The structural assignment for $\mathbf{1 0}$ as the $\Delta^{6,7}$ isomer is based on its NMR spectral data. In particular, the ${ }^{1} \mathrm{H}$ NMR spectrum of $\mathbf{1 0}$ integrates to $18 \mathrm{H}$ atoms, five of which are olefinic. Furthermore, the ${ }^{13} \mathrm{C}$ NMR spectrum of $\mathbf{1 0}$ consisted of 15 signals with five olefinic methine carbons and one quaternary olefinic carbon. The reaction of $( \pm)-9 e$ with the Grubbs 1st generation catalyst led to a complex mixture of products; the use of the Grubbs 2 nd generation catalyst (G-II) gave the 2-azabicyclo[4.4.1] undeca-5,7,9-triene 12, which slowly underwent decomposition in solution. Olefin isomerization has previously been observed as a competitive side reaction of Rucatalyzed olefin metathesis. ${ }^{[14]}$ Presumably, the thermodynamically more stable product $\mathbf{1 0 / 1 2}$ is formed by isomerization of the initially formed $\Delta^{7,8}$ isomer $\mathbf{1 1}$.

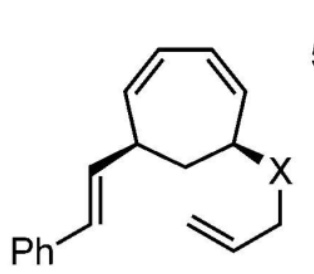

$( \pm)-9 b, X=\mathrm{C}\left(\mathrm{CO}_{2} \mathrm{Me}\right)_{2}$ $( \pm)-9 e, X=N T s$

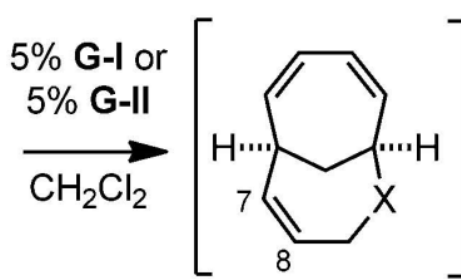

11

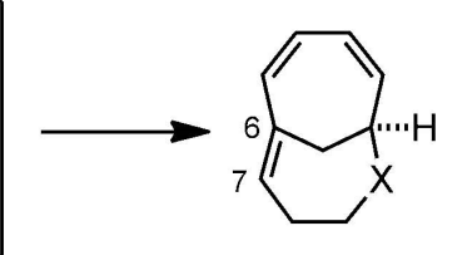

$( \pm)-10, \mathrm{X}=\mathrm{C}\left(\mathrm{CO}_{2} \mathrm{Me}\right)_{2}(88 \%)$

$( \pm)-12, X=$ NTs $(82 \%)$

Scheme 4. Ring-closing metathesis of $9 \mathbf{b}$ and $9 \mathbf{e}$. Ts $=$ tosyl.

Reaction of $( \pm)$-9d with singlet oxygen gave $( \pm)-\mathbf{1 3}$ as a single diastereomer (Scheme 5). Cycloaddition occurs on the diene face opposite to the $s y n-\mathrm{C}^{1} / \mathrm{C}^{6}$ substituents. Similar facial selectivity was 
also observed for substituted cycloheptadiene systems by the groups of Pearson and Seitz. ${ }^{[15]}$

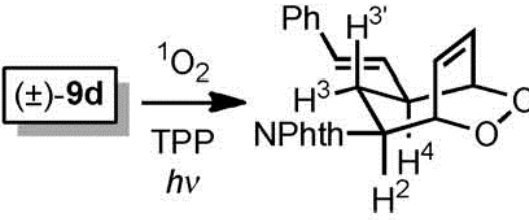

$( \pm)-13(91 \%)$

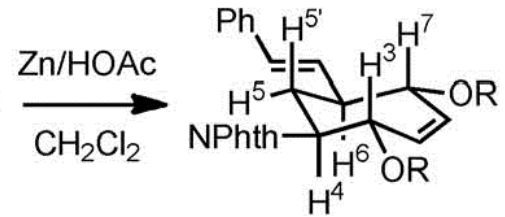

$\mathrm{Ac}_{2} \mathrm{O}( \pm)-14, \mathrm{R}=\mathrm{H}(92 \%)$

pTsCl $( \pm)-15, \mathrm{R}=\mathrm{Ac}(82 \%)$

Scheme 5. Singlet oxygen cycloaddition to $( \pm)-9 d$. TPP $=$ tetraphenylporphorine.

Although the reduction of endoperoxide $\mathbf{1 3}$ with thiourea gave the diol $( \pm) \mathbf{- 1 4}$, these conditions proved to be low yielding and slow, giving only a $50 \%$ yield based on consumed starting material. Alternatively, the use of zinc and acetic acid to reduce 13 proceeded rapidly ( $<1 \mathrm{~h}$ ) to afford 14 in excellent yield; the reaction of 14 with acetic anhydride gave the diacetate $( \pm)-\mathbf{1 5}$. The relative stereochemistries of 13, 14, and 15 were assigned on the basis of their NMR spectral data; in particular, the signal for $\mathrm{H}^{3^{\prime}}$ of 13 appears at $\delta=2.11 \mathrm{ppm}$, whereas the comparable signals for $\mathrm{H}^{5^{\prime}}$ of $\mathbf{1 4}$ and $\mathbf{1 5}$ appear at $\delta=2.73$ and 2.85 ppm, respectively. The relative upfield shift for $\mathrm{H}^{3^{\prime}}$ of $\mathbf{1 3}$ (compared with $\mathrm{H}^{5^{\prime}}$ of 14/15) may be attributed to the anisotropic effects of the proximal $\mathrm{C}^{6}-\mathrm{C}^{7}$ olefin. In addition, the signal for $\mathrm{H}^{4}$ of $\mathbf{1 5}$ appears as a broad triplet at $\delta=4.42 \mathrm{ppm}(J=10.8 \mathrm{~Hz})$; these two large couplings are due to axial-axial couplings to both $\mathrm{H}^{5^{\prime}}$ and $\mathrm{H}^{3}$, thus indicating that $\mathrm{H}^{3}$ occupies an axial orientation in $\mathbf{1 5}$.

Truncation of the styryl group present in $\mathbf{9 d}$ into a hydroxymethyl substitutent was done in the following fashion. Dihydroxylation of $( \pm)$-7d with commercially available AD-mix $\beta$ gave a mixture of diastereomeric diols. Singlet oxygen cycloaddition to the mixture of diols gave a mixture of diastereomeric endoperoxide diols, which undergo cleavage with $\mathrm{Pb}(\mathrm{OAc})_{4}$ to give a single, racemic aldehyde endoperoxide ( \pm )-16 (Scheme 6). This three-step process could be conducted with only a single chromatographic purification of the aldehyde $( \pm)-\mathbf{1 6}$. Reduction of the aldehyde functionality in the presence of the endoperoxide proved challenging; however, this was 
eventually accomplished by using $\mathrm{NaBH}_{3} \mathrm{CN} / \mathrm{AcOH}$ to afford ( \pm )-17 in quantitative yield. Reaction of $\mathbf{1 7}$ with tert-butylchlorodiphenylsilane (TBDPSCl) gave the silyl ether $( \pm)$-18. Reduction of the endoperoxide moiety with $\mathrm{Zn} / \mathrm{HOAc}$ gave the diol $( \pm)$-19. The relative stereochemistries of 16-19 were assigned by comparison of their ${ }^{1} \mathrm{H}$ NMR spectral data with those for 13-15. In particular, the signals for $\mathrm{H}^{3^{\prime}}$ of 16,17 , and 18 appear relatively upfield at $\delta=2.11,1.84$, and $1.78 \mathrm{ppm}$ respectively. The signal for $\mathrm{H}^{4}$ of $\mathbf{1 9}$ appears as a doublet of doublet of doublets at $\delta=4.14 \mathrm{ppm}(J=2.4,10.0,12.4 \mathrm{~Hz})$; the two larger couplings are due to axial-axial couplings to $\mathrm{H}^{5^{\prime}}$ and $\mathrm{H}^{3}$. Dihydroxylation of $\mathbf{1 9}$ with catalytic $\mathrm{OsO}_{4}$ gave a mixture of diastereomeric tetraols $( \pm)-\mathbf{2 0}$ and $( \pm)-\mathbf{2 1}$ (ca. 6:1), from which the major diastereomer can be isolated by careful chromatography. The relative stereochemistry of $\mathbf{2 0}$ was tentatively assigned on the basis of the facial selectivity noted by Kishi et al. ${ }^{[16]}$ for dihydroxylation on the face of an allylic alcohol opposite to the adjacent hydroxyl groups. In this fashion, the racemic protected cycloheptitol $( \pm)-\mathbf{2 0}$ was prepared from (cyclooctatetraene) $\mathrm{Fe}(\mathrm{CO})_{3}$ (1) in 11 steps and six chromatographic purifications in $22 \%$ overall yield.

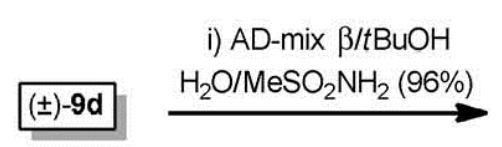

ii) ${ }^{1} \mathrm{O}_{2}, \mathrm{TPP}, h v(92 \%)$

iii) $\mathrm{Pb}(\mathrm{OAc})_{4}(63 \%)$

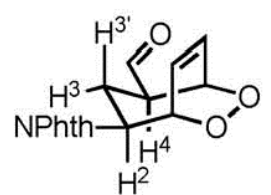

( \pm -16
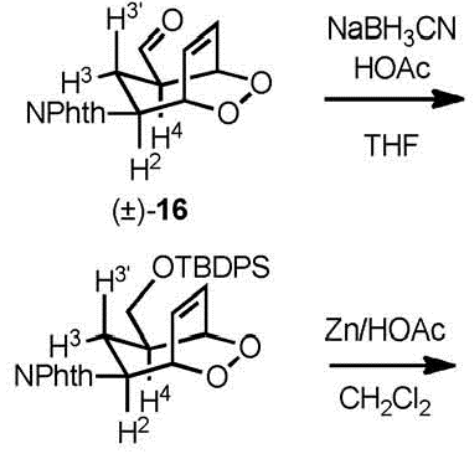

$( \pm)-18(91 \%)$

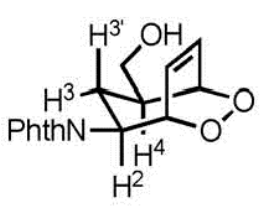

(士)-17 (quant.)

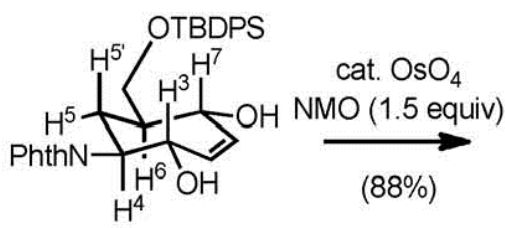

$( \pm)-19(94 \%)$
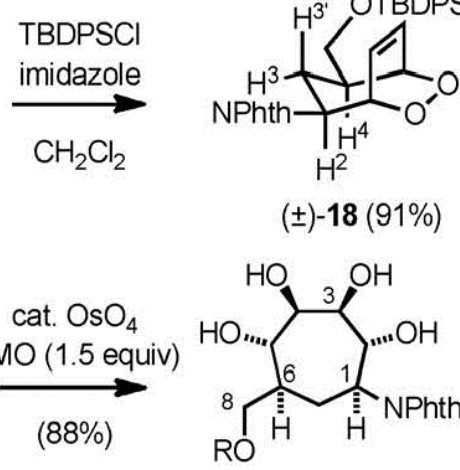

$( \pm)-20 \quad($ ca. $6: 1)$

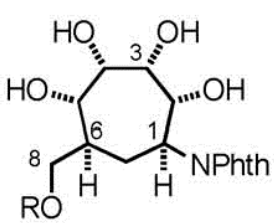

$( \pm)-21$

Scheme 6. Synthesis of protected aminocycloheptitol $( \pm)-\mathbf{2 0}$. NMO $=N$ methylmorpholine $N$-oxide. 
The mixture of diastereomeric diols $(-)-22$ and $(+)-23$ resulting from the asymmetric dihydroxylation of $( \pm)-9 d$ was separable only by preparative thin layer chromatography (Scheme 7). The absolute configuration of the $1^{\prime}, 2^{\prime}$-dihydroxy-2'-phenylethyl side chain for each was assigned based on the Sharpless mnemonic device. ${ }^{[17]}$ Cycloaddition of the less polar cycloheptadiene diastereomer, (-)-22, with Nphenyl-1,3,5-triaza-2,4-dione (PTAD), followed by reaction with 3,5-dinitrobenzoylchloride gave (+)-24. Assignment of the relative stereochemistry of $(+)-\mathbf{2 4}$ was accomplished by single-crystal X-ray diffraction analysis (Figure 2), ${ }^{[18]}$ which also allowed assignment of the configurations of $(-)-22$ and $(+)-23$ as indicated. Separation of diastereomeric endoperoxide diols $(+)-\mathbf{2 5}$ and $(+)-\mathbf{2 6}$ proved more facile and could be accomplished by column chromatography on a $>1 \mathrm{~g}$ scale. Separate singlet oxygen cycloaddition of $(-)-\mathbf{2 2}$ gave $(+)-\mathbf{2 5}$, thus allowing the configurational assignments for $(+)-\mathbf{2 5}$ and $(+)-\mathbf{2 6}$. Separate glycol cleavage of $(+)-$ 25 and $(+)-26$ gave the optically active aldehyde endoperoxides (+)16 and $(-)-16$, which, upon reduction with $\mathrm{NaBH}_{3} \mathrm{CN}$, gave the primary alcohols $(+) \mathbf{- 1 7}$ and $(-)-\mathbf{1 7}$, respectively. Analysis of the ${ }^{1} \mathrm{H}$ NMR spectra ( $\left[D_{6}\right]$ acetone) of the diastereomeric (S)-MTPA ( $\alpha-$ methoxy- $\alpha$-trifluoromethylphenylacetate) esters ${ }^{[16]}$ of $(+)-\mathbf{1 7}$ and (-)$\mathbf{1 7}$ (esters $\mathbf{2 7}$ and 28, respectively) indicated clear separation in one of the olefinic signals (27, $\delta=6.22 \mathrm{ppm} ; \mathbf{2 8}, \delta=6.31 \mathrm{ppm})$. With this method, both $\mathbf{2 7}$ and $\mathbf{2 8}$ were determined to have a >94\% diastereomeric excess $(d e)$. Separate protection of the alcohol $(+)-\mathbf{1 7}$ gave the silyl ether $(+)-\mathbf{1 8}$; reduction of the endoperoxide functionality in $(+) \mathbf{- 1 8}$ gave diol $(+)-19$, and dihydroxylation afforded $(-)-20$ after chromatographic purification. In a similar fashion, (-)17 was successively transformed into $(-)-\mathbf{1 8},(-)-\mathbf{1 9}$, and $(+)-\mathbf{2 0}$, respectively. The overall yield of the optically active protected cycloheptitols $(-)-\mathbf{2 0}$ and $(+)-\mathbf{2 0}$, based on $\mathbf{1}$, is 15.7 and $12.2 \%$, respectively. 

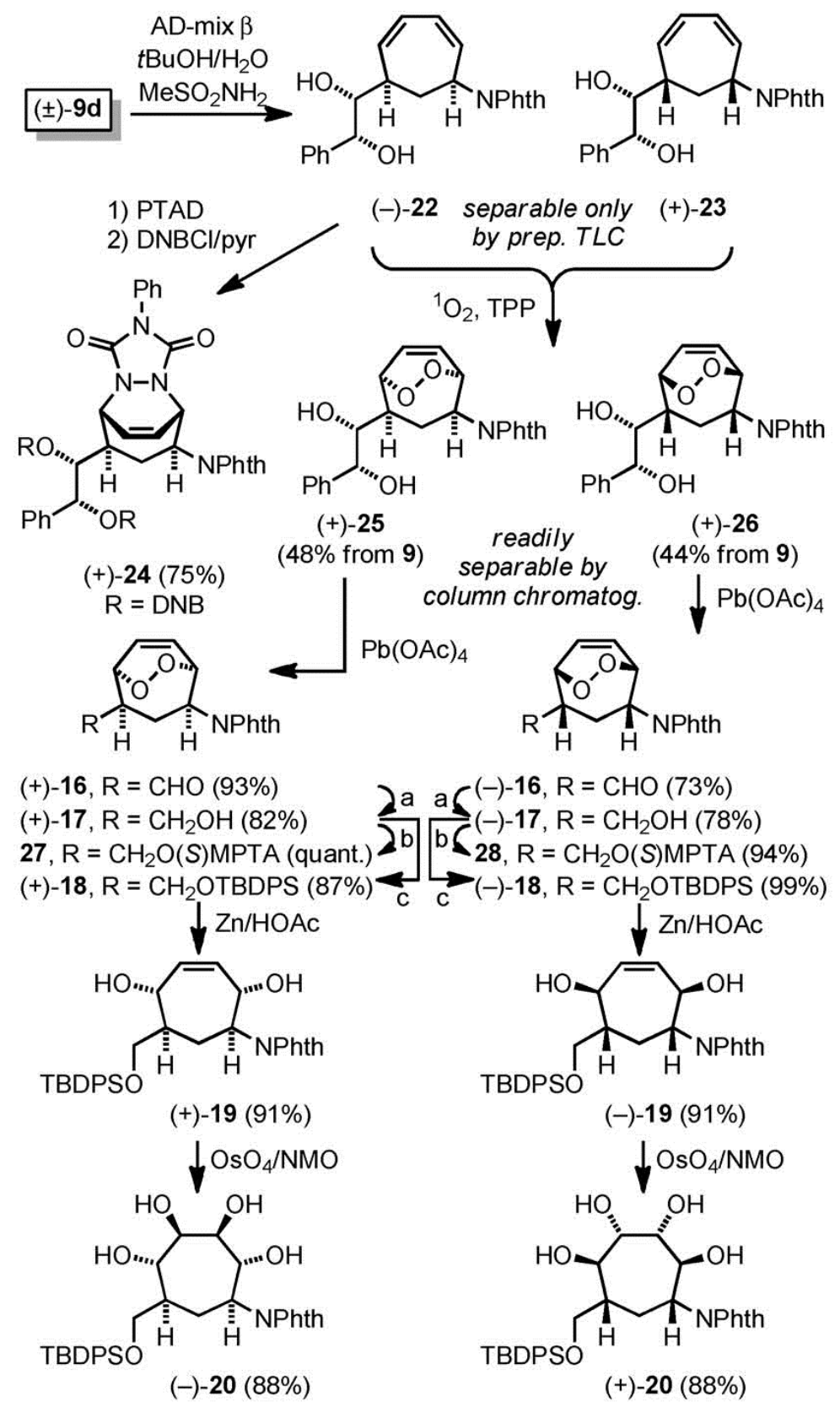

Scheme 7. Separation of the diastereomeric pairs $\mathbf{2 2 / 2 3}$ and $\mathbf{2 5 / 2 6}$, and preparation of the optically active aminocycloheptitols $(-)-\mathbf{2 0}$ and (+)-20 (DNB $=3$,5-dinitrobenzoyl, $\quad$ pyr $=$ pyridine; reagents: a) $\mathrm{NaBH}_{3} \mathrm{CN} /$ HOAc/THF; b) $(S)$-MPTA/ $N, N^{\prime}$-dicyclohexylcarbodiimide (DCC)/4-dimethylaminopyridine (DMAP); c) TBDPSCl/imidazole).

Chemistry, a European Journal, Vol. 19, No. 4 (February 2013): pg. 2330-2336. DOI. This article is (C Wiley-VCH Verlag and permission has been granted for this version to appear in e-Publications@Marquette. Wiley-VCH Verlag does not grant permission for this article to be further copied/distributed or hosted elsewhere without the express permission from Wiley-VCH Verlag. 


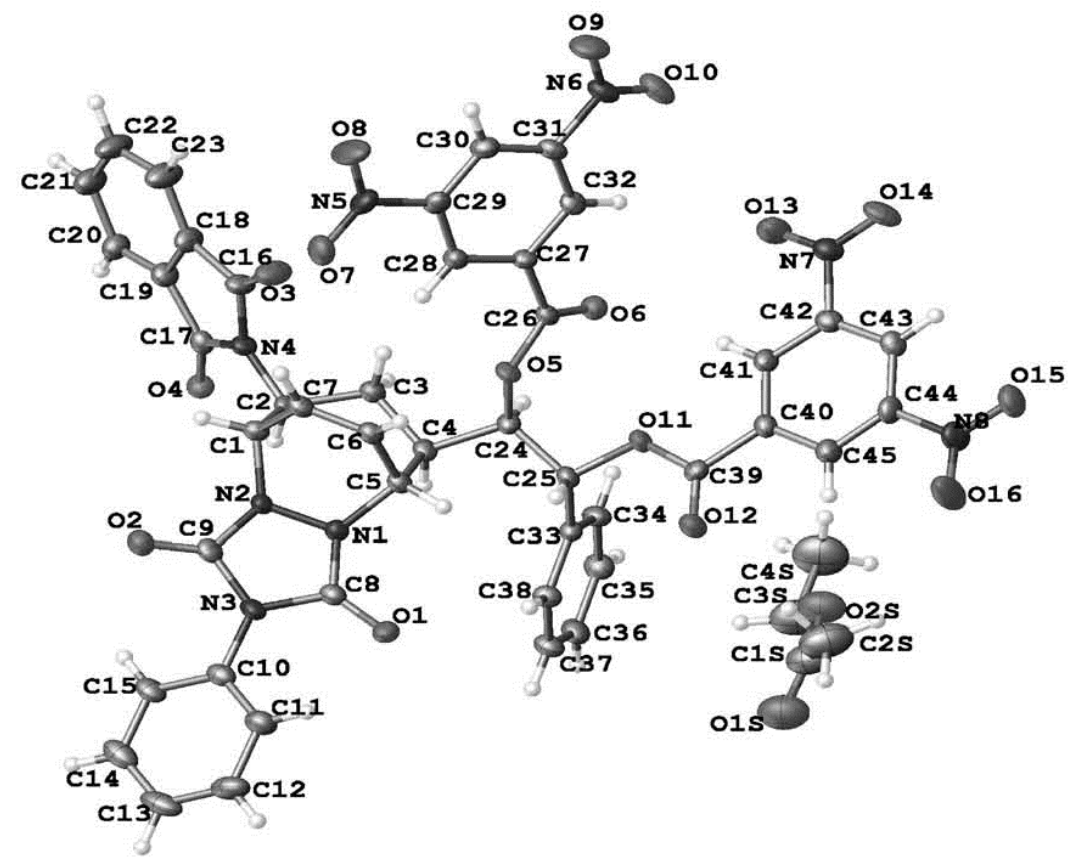

Figure 2. Molecular structure of (+)-24•ethyl acetate.

\section{Conclusion}

An improved preparation of (6-cycloheptadienyl) $\mathrm{Fe}(\mathrm{CO}) 3_{3}^{+}$ $(( \pm)-7)$ was developed and the reactions of this cation with a variety of carbon and heteroatom nucleophiles were examined. Nucleophilic attack occurs preferentially at the less hindered $\mathrm{C}^{1}$ dienyl terminus. Decomplexation of these complexes gave cis-1,6-disubstituted 2,4cycloheptadienes. The racemic free ligand (6-styryl-2,4-cycloheptadien-1-yl)phthalimide $(( \pm)-9 d)$ was transformed into the racemic and optically active, protected aminocycloheptitols ( \pm )-, (-)-, and (+)-20.

\section{Experimental Section}

General methods: All reactions involving moisture- or airsensitive reagents were carried out under a nitrogen atmosphere in oven-dried glassware with anhydrous solvents. THF and diethyl ether were distilled from sodium/benzophenone. Purifications by chromatography were carried out by using flash silica gel $(32-63 \mu)$. NMR spectra were recorded on either a Varian Mercury+ $300 \mathrm{MHz}$ or a permission has been granted for this version to appear in e-Publications@Marquette. Wiley-VCH Verlag does not grant permission for this article to be further copied/distributed or hosted elsewhere without the express permission from Wiley-VCH Verlag. 
Varian UnityInova $400 \mathrm{MHz}$ instrument. $\mathrm{CDCl}_{3}, \mathrm{CD}_{3} \mathrm{OD}$, and $\left[D_{6}\right]$ acetone were purchased from Cambridge Isotope Laboratories. ${ }^{1} \mathrm{H}$ NMR spectra were calibrated to $\delta=7.27$ ppm for residual $\mathrm{CHCl}_{3}, \delta=3.31$ ppm for $\mathrm{CD}_{2} \mathrm{HOD}$, or $\delta=2.05$ ppm for $\left[\mathrm{D}_{5}\right]$ acetone. ${ }^{13} \mathrm{C}$ NMR spectra were calibrated from the central peak at $\delta=77.23 \mathrm{ppm}$ for $\mathrm{CDCl}_{3}$, $\delta=49.15 \mathrm{ppm}$ for $\mathrm{CD}_{3} \mathrm{OD}$, or $\delta=29.92 \mathrm{ppm}$ for $\left[\mathrm{D}_{6}\right]$ acetone. Coupling constants are reported in $\mathrm{Hz}$. The procedures for preparation of compounds 8 f, 8g, 9b, 9c, 9e, 9 f, 12, 13, 15b, (+)-24, and the (S)-Mosher esters of $(+) \mathbf{- 1 7}$ and $(-) \mathbf{- 1 7}$ can be found in the Supporting Information.

\section{Tricarbonyl( $\eta^{5}$-6-cyclohepta-2,4-dien-1-yl)iron(+1)}

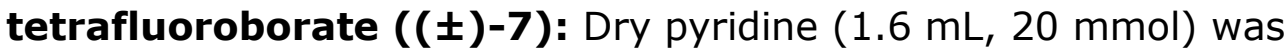
added to a solution of $1(5.00 \mathrm{~g}, 20.5 \mathrm{mmol})$ in dry acetone (25 mL) at $-23^{\circ} \mathrm{C}$ under $\mathrm{N}_{2}$ and the mixture was stirred for $5 \mathrm{~min}$. A solution/suspension of tropylium tetrafluoroborate $(4.00 \mathrm{~g}, 22.5 \mathrm{mmol})$ in dry acetone $(300 \mathrm{~mL})$ was slowly added. The reaction mixture was stirred for $6 \mathrm{~h}$ at $-23^{\circ} \mathrm{C}$, and then for $2 \mathrm{~h}$ at room temperature. The clear reddish solution was concentrated to dryness under reduced pressure. Ether $(100 \mathrm{~mL})$ was added to the solid residue and the slurry was stirred for $2 \mathrm{~h}$ and filtered. This extraction process was repeated three times. The combined ethereal extracts were concentrated. The residue was dissolved in acetic anhydride $(30 \mathrm{~mL})$ and cooled to $0^{\circ} \mathrm{C}$. A solution of tetrafluoroboric acid ( $30 \mathrm{~mL}, 50 \%$ in $\mathrm{H}_{2} \mathrm{O}$ ) and acetic anhydride $(30 \mathrm{~mL})$ was added dropwise to the cooled solution. After stirring for $30 \mathrm{~min}$, the slurry was poured into ether $(2 \mathrm{~L})$. The yellow precipitate was collected by vacuum filtration and the filtrate was washed several times with dry ether to afford $( \pm)-7(6.63 \mathrm{~g}, 76 \%)$ as a bright yellow solid. The ${ }^{1} \mathrm{H}$ NMR spectral data for this cation was identical to the literature values. ${ }^{[6 \mathrm{~d}]}$

\section{Tricarbonyl[dimethyl 2-(6-styryl-2,4-cycloheptadien-}

1yl)propanedioate]iron (( \pm )-8 a): A solution of $n \mathrm{BuLi}(0.20 \mathrm{~mL}$, $1.6 \mathrm{M}$ in hexane, $0.43 \mathrm{mmol}$ ) was added to a stirred solution of dimethyl malonate $(0.060 \mathrm{~mL}, 0.43 \mathrm{mmol})$ in THF $(6 \mathrm{~mL})$ at $0^{\circ} \mathrm{C}$ under nitrogen and then stirred for $30 \mathrm{~min}$. Cation ( \pm )-7 (100 mg, 0.24 $\mathrm{mmol}$ ) was added to the stirring mixture and the mixture was stirred for additional 45 min and gradually warmed to room temperature. The reaction was quenched with water and extracted several times with 
ether, washed with brine, dried $\left(\mathrm{Na}_{2} \mathrm{SO}_{4}\right)$, and concentrated. The residue was purified by column chromatography $\left(\mathrm{SiO}_{2}\right.$, hexanes/ethyl acetate $7: 3$ ) to afford ( \pm )-8a (50 mg, 46\%) as a yellow oil. ${ }^{1} \mathrm{H}$ NMR $\left(400 \mathrm{MHz} \mathrm{CDCl}_{3}\right): \delta=7.35-7.17(\mathrm{~m}, 5 \mathrm{H} ; \mathrm{Ar}-\mathrm{H}), 6.32(\mathrm{~d}, J=16.0 \mathrm{~Hz}$, $\left.1 \mathrm{H} ; \mathrm{H}^{9}\right), 6.01-5.92\left(\mathrm{dd}, J=8.4,15.6 \mathrm{~Hz}, 1 \mathrm{H} ; \mathrm{H}^{8}\right), 5.33-5.26(\mathrm{~m}, 2 \mathrm{H}$; $\left.\mathrm{H}^{3}, \mathrm{H}^{4}\right), 3.74\left(\mathrm{~s}, 3 \mathrm{H} ; \mathrm{OCH}_{3}\right), 3.72\left(\mathrm{~s}, 3 \mathrm{H} ; \mathrm{OCH}_{3}\right), 3.28(\mathrm{~d}, J=6.4 \mathrm{~Hz}$, $\left.1 \mathrm{H} ; \mathrm{CHE}_{2}\right), 2.91-2.72\left(\mathrm{~m}, 4 \mathrm{H} ; \mathrm{H}^{1}, \mathrm{H}^{2}, \mathrm{H}^{5}, \mathrm{H}^{6}\right), 1.05(\mathrm{q}, J=12.6 \mathrm{~Hz}, 1 \mathrm{H}$; $\left.\mathrm{H}^{7}\right)$, 0.90-0.80 ppm (m, $\left.1 \mathrm{H} ; \mathrm{H}^{7^{\prime}}\right) ;{ }^{13} \mathrm{C} \mathrm{NMR}\left(100 \mathrm{MHz}, \mathrm{CDCl}_{3}\right): \delta=210.9$ $(\mathrm{M}-\mathrm{C}=0), 167.6\left(\mathrm{CO}_{2} \mathrm{Me}\right), 137.3,136.3,128.8,128.7,127.4,126.2$, 88.3, 88.0, 61.8, 61.6, 59.8, 58.6, 52.7, 43.0, 39.1, 33.5 ppm; HRMS (FAB) $m / z$ calcd for $\mathrm{C}_{23} \mathrm{H}_{22} \mathrm{O}_{7} \mathrm{Fe}: 466.0715\left[\mathrm{M}^{+}\right]$; found: 466.0707.

\section{TricarbonyI[(6-styryl-2,4-cycloheptadien-1-yl)phthalimide]iron} (( \pm )-8 d): Solid potassium phthalimide $(0.659 \mathrm{~g}, 3.56 \mathrm{mmol})$ was added to a stirred suspension of $( \pm)-7(1.00 \mathrm{~g}, 2.37 \mathrm{mmol})$ in dry $\mathrm{CH}_{2} \mathrm{Cl}_{2}(100 \mathrm{~mL})$ under $\mathrm{N}_{2}$ at room temperature. The reaction mixture was stirred for $12 \mathrm{~h}$ and then quenched with water. The reaction mixture was extracted several times with $\mathrm{CH}_{2} \mathrm{Cl}_{2}$, dried $\left(\mathrm{Na}_{2} \mathrm{SO}_{4}\right)$, and concentrated. The residue was purified by column chromatography $\left(\mathrm{SiO}_{2}\right.$, hexanes/ethyl acetate $\left.4: 1\right)$ to afford $( \pm)-8 \mathbf{d}(820 \mathrm{mg}, 72 \%)$ as a light-yellow solid. M.p. $185-188^{\circ} \mathrm{C} ;{ }^{1} \mathrm{H}$ NMR $\left(400 \mathrm{MHz} \mathrm{CDCl}_{3}\right)$ : $\delta=7.88-7.80$ and 7.78-7.70 (m, 4H; Phth), 7.20-7.35 (m, 5H; $\left.\mathrm{C}_{6} \mathrm{H}_{5}\right)$, $6.38\left(\mathrm{~d}, J=15.6 \mathrm{~Hz}, 1 \mathrm{H} ; \mathrm{H}^{9}\right), 6.01\left(\mathrm{dd}, J=8.2,15.8 \mathrm{~Hz}, 1 \mathrm{H}^{2} \mathrm{H}^{8}\right), 5.57$ (dd, J=5.2, $7.2 \mathrm{~Hz}, 1 \mathrm{H} ; \mathrm{H}^{3}$ or $\mathrm{H}^{4}$ ), 5.44 (dd, J=5.2, $7.4 \mathrm{~Hz}, 1 \mathrm{H}^{\circ} \mathrm{H}^{3}$ or $\left.\mathrm{H}^{4}\right)$, $4.76\left(\mathrm{dd}, J=4.0,12.4 \mathrm{~Hz}, 1 \mathrm{H} ; \mathrm{H}^{1}\right), 3.03-2.95\left(\mathrm{~m}, 2 \mathrm{H} ; \mathrm{H}^{2}, \mathrm{H}^{6}\right)$, $2.75\left(\mathrm{~d}, J=6.8 \mathrm{~Hz}, 1 \mathrm{H} ; \mathrm{H}^{5}\right), 2.01\left(\mathrm{q}, J=12.9 \mathrm{~Hz}, 1 \mathrm{H}^{2} \mathrm{H}^{7^{\prime}}\right), 1.59-1.48$ ppm (br d, J=12.9 Hz, $\left.1 \mathrm{H} ; \mathrm{H}^{7}\right) ;{ }^{13} \mathrm{C} \mathrm{NMR}\left(100 \mathrm{MHz} \mathrm{CDCl}_{3}\right): \delta=210.1$ $(\mathrm{M}-\mathrm{C}=0), 167.9(\mathrm{~N}-\mathrm{C}=\mathrm{O}), 137.3,135.4,134.2,132.0,129.1,128.8$, $127.6,126.3,123.4$, 89.5, 88.5, 61.8, 56.4, 50.7, 43.6, 33.7 ppm; elemental analysis calcd (\%) for $\mathrm{C}_{26} \mathrm{H}_{19} \mathrm{NO}_{5} \mathrm{Fe}$ : C 64.88, $\mathrm{H} 3.98$; found: C 64.85, H 3.97.

(6-Styryl-2,4-cycloheptadien-1-yl)phthalimide (( \pm )-9 d): The decomplexation of $( \pm)-8 d(500 \mathrm{mg}, 1.04 \mathrm{mmol})$ in methanol with ceric ammonium nitrate $(1.71 \mathrm{~g}, 3.12 \mathrm{mmol})$ was carried out in a similar fashion to the decomplexation of $( \pm)-\mathbf{8} \mathbf{c}$. Purification of the residue by column chromatography ( $\mathrm{SiO}_{2}$, hexanes/ethyl acetate 3:1) gave ( \pm )8d (315 mg, 88\%) as a light-yellow solid. M.p. $107-108^{\circ} \mathrm{C} ;{ }^{1} \mathrm{H}$ NMR $\left(400 \mathrm{MHz} \mathrm{CDCl}_{3}\right): \delta=7.88-7.80$ and 7.75-7.56 (ABq, 4H; Phth), 7.35permission has been granted for this version to appear in e-Publications@Marquette. Wiley-VCH Verlag does not grant permission for this article to be further copied/distributed or hosted elsewhere without the express permission from Wiley-VCH Verlag. 
NOT THE PUBLISHED VERSION; this is the author's final, peer-reviewed manuscript. The published version may be accessed by following the link in the citation at the bottom of the page.

$7.17\left(\mathrm{~m}, 5 \mathrm{H} ; \mathrm{C}_{6} \mathrm{H}_{5}\right), 6.45\left(\mathrm{~d}, J=16.0 \mathrm{~Hz}, 1 \mathrm{H} ; \mathrm{H}^{9}\right), 6.16(\mathrm{dd}, J=8.2$, $\left.15.9 \mathrm{~Hz}, 1 \mathrm{H} ; \mathrm{H}^{8}\right), 5.88-5.75(\mathrm{~m}, 4 \mathrm{H} ; \mathrm{CH}=\mathrm{CH}-\mathrm{CH}=\mathrm{CH}), 5.25$ (br d, $\left.J=11.2 \mathrm{~Hz}, 1 \mathrm{H} ; \mathrm{H}^{1}\right), 3.60-3.50\left(\mathrm{~m}, 1 \mathrm{H} ; \mathrm{H}^{6}\right), 2.84(\mathrm{dt}, J=11.2,12.8 \mathrm{~Hz}$, $\left.1 \mathrm{H} ; \mathrm{H}^{7}\right)$, 2.06-2.00 ppm (m, $\left.1 \mathrm{H} ; \mathrm{H}^{7^{\prime}}\right) ;{ }^{13} \mathrm{C} \mathrm{NMR}\left(100 \mathrm{MHz}, \mathrm{CDCl}_{3}\right)$ : $\delta=167.7$ (CO) , 137.2, 136.9, 134.1, 133.6, 132.2, 132.0, 129.8, $128.6,127.3,126.2,124.0,123.9,123.3,50.5\left(C^{1}\right), 44.0\left(C^{6}\right), 38.2$ ppm ( $\mathrm{C}^{7}$ ); elemental analysis calcd (\%) for $\mathrm{C}_{23} \mathrm{H}_{19} \mathrm{NO}_{2}$ : C 80.92, $\mathrm{H}$ 5.61; found: C 80.61, H 5.67.

\section{rac-2-Formyl-4-phthalimido-6,7-dioxabicyclo[3.2.2]non-8-ene} ((士)-16): Methane sulfonamide $(60 \mathrm{mg}, 0.59 \mathrm{mmol})$ was added at room temperature to a mixture of $( \pm)-9 \mathbf{d}(1.00 \mathrm{~g}, 2.93 \mathrm{mmol})$ in a mixture of $\mathrm{tBuOH}(20 \mathrm{~mL})$, ethyl acetate $(5 \mathrm{~mL})$, and water $(25 \mathrm{~mL})$. The mixture was cooled to $0^{\circ} \mathrm{C}$ with an ice bath and then solid AD-mix $\beta(4.325 \mathrm{~g})$ was added. The reaction mixture was stirred for $34 \mathrm{~h}$ at $0^{\circ} \mathrm{C}$, after which time, monitoring by TLC indicated the disappearance of starting material. The reaction was quenched with water $(20 \mathrm{~mL})$. The mixture was transferred to a separatory funnel and the top, organic layer was decanted. The aqueous layer was extracted several times with ethyl acetate and the combined organic layers were dried $\left(\mathrm{NaSO}_{4}\right)$, concentrated, and the residue was purified by column chromatography $\left(\mathrm{SiO}_{2}\right.$, hexanes/ethyl acetate $\left.=2: 3\right)$ to afford a $1: 1$ mixture of diastereomeric diols $(1.050 \mathrm{~g}, 96 \%)$ as a colorless foam. This material was used in the next step without further characterization. Tetraphenylporphorine $(15 \mathrm{mg})$ was added to a solution of the diol mixture $(1.00 \mathrm{~g}, 2.67 \mathrm{mmol})$ in $\mathrm{CHCl}_{3}(30 \mathrm{~mL})$. The darkpurple solution was irradiated for a $5 \mathrm{~h}$ period with a commercially available $100 \mathrm{~W}$ halogen lamp while ultra-pure $\mathrm{O}_{2}$ was bubbled through the solution. The organic solvent was removed to afford a mixture of diastereomeric endoperoxide diols $(1.00 \mathrm{~g}, 92 \%)$ that were used in the next step without further purification. Solid $\mathrm{Pb}(\mathrm{OAc})_{4}(544 \mathrm{mg}, 1.23$ $\mathrm{mmol}$ ) was added to a solution of the endoperoxide diols (500 mg, $1.29 \mathrm{mmol})$ in dry $\mathrm{CH}_{2} \mathrm{Cl}_{2}(25 \mathrm{~mL})$ at $-78^{\circ} \mathrm{C}$. The mixture was stirred for $30 \mathrm{~min}$, and then quenched with water. The mixture was extracted several times with $\mathrm{CH}_{2} \mathrm{Cl}_{2}$, and the combined extracts were dried $\left(\mathrm{Na}_{2} \mathrm{SO}_{4}\right)$ and concentrated. Purification of the residue by column chromatography $\left(\mathrm{SiO}_{2}\right.$, hexanes/ethyl acetate 3:2) gave $( \pm)$-16 (244 $\mathrm{mg}, 63 \%)$ as a colorless solid. M.p. $179-180^{\circ} \mathrm{C} ;{ }^{1} \mathrm{H}$ NMR $(400 \mathrm{MHz}$, $\left.\mathrm{CDCl}_{3}\right): \delta=9.65(\mathrm{~s}, 1 \mathrm{H} ; \mathrm{CHO}), 7.88-7.78(\mathrm{~m}, 4 \mathrm{H} ; \mathrm{Phth}), 6.77$ (dd, 
$J=7.2,9.3 \mathrm{~Hz}, 1 \mathrm{H} ; \mathrm{CH}=\mathrm{CH}), 6.43$ (dd, $J=7.2,9.3 \mathrm{~Hz}, 1 \mathrm{H} ; \mathrm{CH}=\mathrm{CH}$ ), $5.26\left(\mathrm{~d}, J=7.2 \mathrm{~Hz}, 1 \mathrm{H} ; \mathrm{H}^{1}\right), 4.86-4.80\left(\mathrm{~m}, 2 \mathrm{H} ; \mathrm{H}^{2}, \mathrm{H}^{5}\right), 3.16(\mathrm{dd}$, $\left.J=5.0,13.0 \mathrm{~Hz}, 1 \mathrm{H} ; \mathrm{H}^{4}\right), 2.11\left(\mathrm{q}, J=13.0 \mathrm{~Hz}, 1 \mathrm{H} ; \mathrm{H}^{3^{\prime}}\right), 2.05-1.97 \mathrm{ppm}$ $\left(\mathrm{m}, 1 \mathrm{H} ; \mathrm{H}^{3}\right) ;{ }^{13} \mathrm{C} \mathrm{NMR}\left(100 \mathrm{MHz} \mathrm{CDCl}_{3}\right): \delta=199.0(\mathrm{CHO}), 167.7(\mathrm{~N}-$ $\mathrm{C}=0), 134.6,131.7,129.8,124.6,123.7,80.0,75.4,54.3,52.1,23.9$ ppm; HRMS (ESI): $\mathrm{m} / z$ calcd for $\mathrm{C}_{16} \mathrm{H}_{13} \mathrm{NO}_{5}+\mathrm{Na}^{+}: 322.0686\left[\mathrm{M}+\mathrm{Na}^{+}\right]$; found: 322.0685.

Asymmetric dihydroxylation of ( \pm )-9d: A $25 \mathrm{~mL}$ round-bottomed flask was charged with a mixture of $t \mathrm{BuOH}(3 \mathrm{~mL})$ and water $(3 \mathrm{~mL})$ and stirred for $5 \mathrm{~min}$ at room temperature. Solid AD-mix $\beta(0.826 \mathrm{~g})$ was added to the stirring solution followed by the addition of methane sulfonamide $(60 \mathrm{mg}, 0.59 \mathrm{mmol})$. The mixture was stirred until the two layers were separated. The mixture was cooled to $0^{\circ} \mathrm{C}$, at which point an inorganic salt was precipitated. Alkene ( $200 \mathrm{mg}, 0.59 \mathrm{mmol}$ ) was added in one portion and the mixture was stirred for $72 \mathrm{~h}$ while maintaining the temperature at $0^{\circ} \mathrm{C}$. The reaction mixture was quenched with water, extracted several times with ethyl acetate, and the combined extracts were washed with brine. The organic layer was concentrated under reduced pressure. The residue was purified by column chromatography $\left(\mathrm{SiO}_{2}\right.$, hexanes/ethyl acetate $\left.=1: 1\right)$ to give a mixture of diastereomers as a colorless oily liquid (149 mg, 71\%). The diastereomers could be separated by preparative TLC $\left(\mathrm{SiO}_{2}\right.$, hexanes/ethyl ether $1: 1$ ) to afford a less polar fraction (-)-22 and a more polar fraction $(+)-\mathbf{2 3}$.

\section{R-(1'R,2'R-Dihydroxy-2'-phenylethyl)-2,4-cycloheptadien-1S-} yl)phthalimide((-)-22): $[\alpha]_{\mathrm{D}}^{23}=-5.1$ ( $c=0.500$ in $\left.\mathrm{CH}_{2} \mathrm{Cl}_{2}\right) ;{ }^{1} \mathrm{H} \mathrm{NMR}$ (300 $\left.\mathrm{MHz} \mathrm{CDCl}_{3}\right): \delta=7.80-7.72(\mathrm{~m}, 2 \mathrm{H}$; Phth), 7.68-7.60 (m, 2H; Phth), 7.35-7.29 (m, 5H; $\left.\mathrm{C}_{6} \mathrm{H}_{5}\right), 5.90-5.77(\mathrm{~m}, 3 \mathrm{H}$; olefinic $\mathrm{H}), 5.57$ (dd, $J=1.5,11.1 \mathrm{~Hz}, 1 \mathrm{H}$; olefinic $\mathrm{H}), 4.99$ (qd, $J=2.8,11.1 \mathrm{~Hz}, 1 \mathrm{H}$; $\left.\mathrm{H}^{1}\right), 4.65\left(\mathrm{~d}, J=6.9 \mathrm{~Hz}, 1 \mathrm{H} ; \mathrm{H}^{9}\right), 3.68-3.60\left(\mathrm{~m}, 1 \mathrm{H} ; \mathrm{H}^{8}\right), 2.95(\mathrm{br} \mathrm{s}$, $1 \mathrm{H} ; \mathrm{OH}), 2.86\left(\mathrm{q}, J=11.4 \mathrm{~Hz}, 1 \mathrm{H} ; \mathrm{H}^{7}\right), 2.71(\mathrm{~d}, J=4.2 \mathrm{~Hz}, 1 \mathrm{H} ; \mathrm{OH})$, 2.60 (br d, $J=11.1 \mathrm{~Hz}, 1 \mathrm{H} ; \mathrm{H}^{6}$ ), $1.82 \mathrm{ppm}$ (br d, $J=12.9 \mathrm{~Hz}, 1 \mathrm{H}^{\prime} \mathrm{H}^{7^{\prime}}$ ); ${ }^{13} \mathrm{C} \mathrm{NMR}\left(75 \mathrm{MHz} \mathrm{CDCl}_{3}\right): \delta=167.9,140.9,134.2,133.1,132.9$, $132.1,128.9,128.5,126.9,125.8,124.6,123.4,79.2,75.1,50.9$, 41.5, 35.4 ppm; elemental analysis calcd (\%) for $\mathrm{C}_{23} \mathrm{H}_{2} 1 \mathrm{O}_{4} \mathrm{~N} \cdot 3 / 4 \mathrm{H}_{2} \mathrm{O}$ :

C 71.02, H 5.83; found: C 71.19, H 5.83.

Chemistry, a European Journal, Vol. 19, No. 4 (February 2013): pg. 2330-2336. DOI. This article is (C Wiley-VCH Verlag and permission has been granted for this version to appear in e-Publications@Marquette. Wiley-VCH Verlag does not grant permission for this article to be further copied/distributed or hosted elsewhere without the express permission from Wiley-VCH Verlag. 
6S-(1'R, 2'R-Dihydroxy-2'-phenylethyl)-2,4-cycloheptadien-1Ryl)phthalimide $((+)-23)$ : $[\alpha]_{\mathrm{D}}^{23}=+74.1\left(c=0.486\right.$ in $\left.\mathrm{CH}_{2} \mathrm{Cl}_{2}\right) ;{ }^{1} \mathrm{H}$ NMR (300 MHz, $\left.\mathrm{CDCl}_{3}\right): \delta=7.90-7.80(\mathrm{~m}, 2 \mathrm{H}$; Phth), 7.78-7.70 (m, $2 \mathrm{H}$; Phth), 7.41-7.25 (m, $\left.5 \mathrm{H} ; \mathrm{C}_{6} \mathrm{H}_{5}\right), 5.90-5.76(\mathrm{~m}, 3 \mathrm{H}$; olefinic $\mathrm{H}), 5.67$ (br d, J=11.7 Hz, $1 \mathrm{H}$; olefinic $\mathrm{H}), 5.05\left(\mathrm{br} \mathrm{d}, J=9.6 \mathrm{~Hz}, 1 \mathrm{H} ; \mathrm{H}^{1}\right), 4.68$ $\left(\mathrm{d}, J=6.9 \mathrm{~Hz}, 1 \mathrm{H} ; \mathrm{H}^{9}\right), 3.84-3.77\left(\mathrm{~m}, 1 \mathrm{H} ; \mathrm{H}^{8}\right), 3.12(\mathrm{br} \mathrm{s}, 1 \mathrm{H} ; \mathrm{OH})$, $2.91(\mathrm{br} \mathrm{s}, 1 \mathrm{H} ; \mathrm{OH}), 2.71\left(\mathrm{td}, J=11.1,12.9 \mathrm{~Hz}, 1 \mathrm{H} ; \mathrm{H}^{7}\right), 2.58(\mathrm{br} \mathrm{d}$, $\left.J=10.8 \mathrm{~Hz}, 1 \mathrm{H} ; \mathrm{H}^{6}\right), 1.98 \mathrm{ppm}\left(\mathrm{br} \mathrm{s}, 1 \mathrm{H}^{\circ} \mathrm{H}^{7}\right) ;{ }^{13} \mathrm{C} \mathrm{NMR}(75 \mathrm{MHz}$, $\left.\mathrm{CDCl}_{3}\right): \delta=167.9(\mathrm{~N}-\mathrm{C}=0), 141.0,136.5,134.2,132.9,132.2,128.9$, $128.5,126.7,125.4,124.5,123.5,79.3,75.3,51.2,41.2,31.6$ ppm.

\section{Singlet oxygen cycloaddition of diastereomeric diol mixture: A} $50 \mathrm{~mL}$ two-necked round-bottomed flask, equipped with a condenser, was charged with dienediol $(1.30 \mathrm{~g}, 3.46 \mathrm{mmol})$, dry $\mathrm{CHCl}_{3}(30 \mathrm{~mL})$, and tetraphenylporphorine $(25 \mathrm{mg}, 0.041 \mathrm{mmol})$. The dark-purple solution was irradiated with a $100 \mathrm{~W}$ tungsten-halogen lamp for $6 \mathrm{~h}$ while ultra-pure $\mathrm{O}_{2}$ was bubbled through the solution. The reaction mixture was concentrated under vacuum and the residue was purified by column chromatography $\left(\mathrm{SiO}_{2}\right.$, hexanes/ethyl acetate 3:2) to give a less polar endoperoxide $(+)-\mathbf{2 5}(671 \mathrm{mg}, 48 \%)$ and a more polar endoperoxide (+)-26 (626 mg, 44\%) as foamy compounds.

\section{4-(1'R,2' $R$-Dihydroxy-2'-phenylethyl)-2-phthalimido-6S,7R-} dioxabicyclo-[3.2.2]non-8-ene $((+)-25)$ : M.p. $97-98^{\circ} \mathrm{C} ;[\alpha]_{\mathrm{D}}^{23}$ $=+41.0\left(c=0.0011\right.$ in $\left.\mathrm{CH}_{2} \mathrm{Cl}_{2}\right) ;{ }^{1} \mathrm{H}$ NMR $\left(300 \mathrm{MHz}, \mathrm{CDCl}_{3}\right): \delta=7.85-7.71$ (m, 4H; Phth), 7.39-7.26 (m, 5H; $\left.\mathrm{C}_{6} \mathrm{H}_{5}\right), 6.71$ (dd, J=7.2, $9.1 \mathrm{~Hz}, 1 \mathrm{H}$; $\mathrm{CH}=\mathrm{CH}), 6.41(\mathrm{dd}, J=7.5,8.4 \mathrm{~Hz}, 1 \mathrm{H} ; \mathrm{CH}=\mathrm{CH}), 5.18(\mathrm{~d}, J=7.2 \mathrm{~Hz}$, $\left.1 \mathrm{H} ; \mathrm{H}^{1}\right), 4.73-4.68\left(\mathrm{~m}, 3 \mathrm{H} ; \mathrm{H}^{2}, \mathrm{H}^{5}, \mathrm{H}^{10}\right), 3.43-3.39$ (narrow $\mathrm{m}, 1 \mathrm{H}$; $\left.\mathrm{H}^{9}\right), 2.68(\mathrm{~d}, J=3.9 \mathrm{~Hz}, 1 \mathrm{H} ; \mathrm{OH}), 2.48(\mathrm{~d}, J=4.8 \mathrm{~Hz}, 1 \mathrm{H} ; \mathrm{OH}), 2.29$ (dd, J=5.7, $\left.12.6 \mathrm{~Hz}, 1 \mathrm{H} ; \mathrm{H}^{3}\right), 2.10-2.03\left(\mathrm{~m}, 1 \mathrm{H} ; \mathrm{H}^{4}\right), 1.60 \mathrm{ppm}(\mathrm{br} \mathrm{d}$, $\left.\mathrm{J}=12.6 \mathrm{~Hz}, 1 \mathrm{H} ; \mathrm{H}^{3}\right) ;{ }^{13} \mathrm{C} \mathrm{NMR}\left(75 \mathrm{MHz}, \mathrm{CDCl}_{3}\right): \delta=167.8,141.0,134.5$, $131.8,128.9,128.8,128.4,126.5,125.8,123.6,79.8,78.1,76.9$, 74.0, 52.2, 43.8, $27.6 \mathrm{ppm}$; HRMS (ESI): $\mathrm{m} / \mathrm{z}$ calcd for $\mathrm{C}_{23} \mathrm{H}_{21} \mathrm{NO}_{6}+\mathrm{Na}^{+}: 430.1261\left[\mathrm{M}+\mathrm{Na}^{+}\right]$; found: 430.1254 .

\section{4-(1'R, 2' $R$-Dihydroxy-2'-phenylethyl)-2-phthalimido-6R,7S-} dioxabicyclo-[3.2.2]non-8-ene ((+)-26): $[\alpha]_{\mathrm{D}}^{23}=+33(c=0.0011$ in $\left.\mathrm{CH}_{2} \mathrm{Cl}_{2}\right) ;{ }^{1} \mathrm{H}$ NMR $\left(300 \mathrm{MHz}, \mathrm{CDCl}_{3}\right): \delta=7.90-7.70$ (m, 4H; Phth), 7.40$7.25\left(\mathrm{~m}, 5 \mathrm{H} ; \mathrm{C}_{6} \mathrm{H}_{5}\right), 6.65$ (dd, J=7.6, $\left.8.8 \mathrm{~Hz}, 1 \mathrm{H} ; \mathrm{CH}=\mathrm{CH}\right), 6.47$ (dd, permission has been granted for this version to appear in e-Publications@Marquette. Wiley-VCH Verlag does not grant permission for this article to be further copied/distributed or hosted elsewhere without the express permission from Wiley-VCH Verlag. 
$J=8.0,8.8 \mathrm{~Hz}, 1 \mathrm{H} ; \mathrm{CH}=\mathrm{CH}), 4.73-4.65(\mathrm{~m}, 2 \mathrm{H}), 4.58(\mathrm{dd}, J=4.4,12.8$ $\left.\mathrm{Hz}, 1 \mathrm{H} ; \mathrm{H}^{2}\right), 4.49(\mathrm{dd}, \mathrm{J}=2.4,6.9 \mathrm{~Hz}, 1 \mathrm{H}$ ), 3.80-3.75 (narrow $\mathrm{m}, 1 \mathrm{H}$; $\left.\mathrm{H}^{9}\right), 3.25-3.10$ (br s, $\left.2 \mathrm{H} ; 2 \mathrm{OH}\right), 2.23\left(\mathrm{q}, J=12.6 \mathrm{~Hz}, 1 \mathrm{H} ; \mathrm{H}^{3^{\prime}}\right), 2.07-$ $1.98\left(\mathrm{~m}, 1 \mathrm{H} ; \mathrm{H}^{4}\right), 1.65 \mathrm{ppm}\left(\mathrm{td}, J=4.0,12.8 \mathrm{~Hz}, 1 \mathrm{H} ; \mathrm{H}^{3}\right) ;{ }^{13} \mathrm{C}$ NMR (75 $\left.\mathrm{MHz}_{1} \mathrm{CDCl}_{3}\right): \delta=167.8,140.7,134.4,131.8,129.0,128.7,127.3$, $126.6,126.5,123.5,81.4,79.7,77.0,75.1,52.4,44.0,23.4$ ppm. HRMS (ESI): $m / z$ calcd for $\mathrm{C}_{23} \mathrm{H}_{21} \mathrm{NO}_{6}+\mathrm{Na}^{+}: 430.1261\left[\mathrm{M}+\mathrm{Na}^{+}\right]$; found: 430.1252.

\section{R-Formyl-4S-phthalimido-6S,7R-dioxabicyclo[3.2.2] non-8-ene} ((+)-16): solid $\mathrm{Pb}(\mathrm{OAc})_{4}(1.061 \mathrm{~g}, 2.396 \mathrm{mmol})$ was added to a solution of less polar endoperoxide diol (+)-25 (650 mg, $1.60 \mathrm{mmol})$ dissolved in dry $\mathrm{CH}_{2} \mathrm{Cl}_{2}(30 \mathrm{~mL})$. The reaction mixture was stirred for 15 min and then quenched with water, and the mixture was extracted several times with $\mathrm{CH}_{2} \mathrm{Cl}_{2}$. The combined organic extracts were dried $\left(\mathrm{Na}_{2} \mathrm{SO}_{4}\right)$ and concentrated, and the residue was purified by column chromatography $\left(\mathrm{SiO}_{2}\right.$, hexanes/ethyl acetate 3:2) to afford $(+)-16$ (439 $\mathrm{mg}, 93 \%$ ) as a colorless solid. M.p. $55-57^{\circ} \mathrm{C} ;[\alpha]_{\mathrm{D}}^{20}=+88$ ( $c=0.0011$ in $\mathrm{CH}_{2} \mathrm{Cl}_{2}$ ); the NMR spectral data for $(+)-16$ was identical to that for the racemic material $( \pm) \mathbf{- 1 6}$.

\section{S-Formyl-4R-phthalimido-6R,7S-dioxabicyclo[3.2.2] non-8-ene} ((-)-16): The glycol cleavage of endoperoxide diol (+)-26 (46 mg, $0.11 \mathrm{mmol}$ ) was carried out in a similar fashion to the glycol cleavage of $(+)-\mathbf{2 5}$ to afford $(-)-\mathbf{1 6}(23 \mathrm{mg}, 73 \%)$. M.p. $55-57^{\circ} \mathrm{C} ;[\alpha]_{\mathrm{D}}^{20}=-100$ $\left(c=0.287\right.$ in $\mathrm{CH}_{2} \mathrm{Cl}_{2}$ ). The NMR spectral data for $(-) \mathbf{- 1 6}$ was identical to that for the racemic material $( \pm) \mathbf{- 1 6}$.

\section{4-Hydroxymethyl-2-phthalimido-8,9-dioxabicyclo[3.2.2]non-6- ene ( $( \pm)-17)$ : Compound $( \pm)-16(50.0 \mathrm{mg}, 0.167 \mathrm{mmol})$ was added} to a solution of THF (10 mL) and glacial acetic acid ( $2 \mathrm{~mL})$ and the mixture was stirred for $5 \mathrm{~min}$. Solid $\mathrm{NaBH}_{3} \mathrm{CN}$ (16 mg, $0.254 \mathrm{mmol}$ ) was added, and monitoring of the reaction by TLC indicated complete disappearance of starting material after $1 \mathrm{~h}$. The solvent was evaporated and the residue was purified by column chromatography $\left(\mathrm{SiO}_{2}\right.$, hexanes/ethyl acetate 2:3) to afford ( \pm )-17 (51 mg, quant.) as a colorless solid. M.p. $139-141^{\circ} \mathrm{C} ;{ }^{1} \mathrm{H}$ NMR $\left(400 \mathrm{MHz}, \mathrm{CDCl}_{3}\right): \delta=7.90-$ 7.72 (m, 4H; Phth), 6.77 (dd, J=7.2, $9.8 \mathrm{~Hz}, 1 \mathrm{H} ; \mathrm{CH}=\mathrm{CH}$ ), 6.45 (dd, $J=6.8,9.8 \mathrm{~Hz}, 1 \mathrm{H} ; \mathrm{CH}=\mathrm{CH}), 4.98\left(\mathrm{~d}, J=7.2 \mathrm{~Hz}, 1 \mathrm{H} ; \mathrm{H}^{1}\right), 4.81-4.73$ 
$\left(\mathrm{m}, 2 \mathrm{H} ; \mathrm{H}^{2}, \mathrm{H}^{5}\right), 3.66-3.60\left(\mathrm{~m}, 1 \mathrm{H} ; \mathrm{CH}_{2} \mathrm{O}\right), 3.47-3.38\left(\mathrm{~m}, 1 \mathrm{H} ; \mathrm{CH}_{2} \mathrm{O}\right)$, 2.40-2.31 (m, $\left.1 \mathrm{H} ; \mathrm{H}^{4}\right), 1.84\left(\mathrm{q}, J=12.8 \mathrm{~Hz}, 1 \mathrm{H} ; \mathrm{H}^{3^{\prime}}\right), 1.61(\mathrm{td}, J=4.4$, $\left.12.8 \mathrm{~Hz}, 1 \mathrm{H} ; \mathrm{H}^{3}\right), 1.53 \mathrm{ppm}$ (br s, $\left.1 \mathrm{H} ; \mathrm{OH}\right) ;{ }^{13} \mathrm{C} \mathrm{NMR}(100 \mathrm{MHz}$, $\left[D_{6}\right.$ ]acetone): $\delta=167.8,134.5,131.9,129.7,124.9,123.6,80.0,78.3$, 64.2, 52.3, 44.7, 26.6 ppm; HRMS (ESI): $\mathrm{m} / \mathrm{z}$ calcd for $\mathrm{C}_{16} \mathrm{H}_{15} \mathrm{NO}_{5}+\mathrm{Na}^{+}: 324.0842\left[\mathrm{M}+\mathrm{Na}^{+}\right]$; found: 324.0839 .

4S-Hydroxymethyl-2S-phthalimido-8,9-dioxabicyclo[3.2.2]non6-ene $((+)-17)$ : The reduction of $(+)-16(400 \mathrm{mg}, 1.34 \mathrm{mmol})$ was carried out in a similar fashion to the reduction of $( \pm)-\mathbf{1 6}$ to afford the optically active primary alcohol (+)-17 (329 mg, 82\%). M.p. 163$166^{\circ} \mathrm{C} ;[\alpha]_{\mathrm{D}}^{20}=+119\left(c=0.00176\right.$ in $\left.\mathrm{CH}_{2} \mathrm{Cl}_{2}\right)$. The NMR spectral data for $(+) \mathbf{- 1 7}$ was identical to that for the racemic compound $( \pm)-\mathbf{1 7}$.

\section{R-Hydroxymethyl-2R-phthalimido-8,9-dioxabicyclo[3.2.2] non-} 6-ene (( \pm )-17): The reduction of (-)-16 (360 $\mathrm{mg}, 1.204 \mathrm{mmol}$ ) was carried out in a similar fashion to the reduction of $( \pm) \mathbf{- 1 6}$, to afford the optically active primary alcohol (-)-17 (281 mg, 78\%). M.p. 167$169^{\circ} \mathrm{C} ;[\alpha]_{\mathrm{D}}^{20}=-95\left(\mathrm{C}=0.00082\right.$ in $\left.\mathrm{CH}_{2} \mathrm{Cl}_{2}\right)$. The NMR spectral data for $(-) \mathbf{1 7}$ was identical to that for the racemic compound $( \pm) \mathbf{- 1 7}$.

\section{4-(tert-Butyldiphenylsilyloxy)methyl-2-phthalimido-8,9-} dioxabicyclo-[3.2.2] non-6-ene (( \pm )-18): Imidazole (18 mg, 0.266 mmol) was added to a solution of $( \pm)-17(40.0 \mathrm{mg}, 0.133 \mathrm{mmol})$ in freshly distilled $\mathrm{CH}_{2} \mathrm{Cl}_{2}(5 \mathrm{~mL})$ cooled to $0^{\circ} \mathrm{C}$, and was followed by the dropwise addition of tert-butylchlorodiphenylsilane $(44 \mathrm{mg}, 0.159$ $\mathrm{mmol}$ ) over a period of $15 \mathrm{~min}$ at $0^{\circ} \mathrm{C}$. After stirring at room temperature for $3 \mathrm{~h}$, monitoring of the reaction mixture by TLC indicated the complete disappearance of starting material. The mixture was quenched with water and extracted several times with $\mathrm{CH}_{2} \mathrm{Cl}_{2}$. The combined extracts were concentrated and the residue was purified by column chromatography $\left(\mathrm{SiO}_{2}\right.$, hexanes/ethyl acetate $\left.4: 1\right)$ to give ( \pm )18 (65 mg, 91\%) as a colorless foam. M.p. 44-46 ${ }^{\circ} \mathrm{C} ;{ }^{1} \mathrm{H}$ NMR (400 $\left.\mathrm{MHz} \mathrm{CDCl}_{3}\right): \delta=7.87-7.70(\mathrm{~m}, 4 \mathrm{H}$; Phth), 7.65-7.60 (m, 4H; Ar-H), $7.48-7.37$ (m, 6H; Ar-H), 6.71 (ddd, J=1.2, 7.2, 9.6 Hz, $1 \mathrm{H} ; \mathrm{CH}=\mathrm{CH}$ ), 6.25 (ddd, 0.8, 7.2, 9.2 Hz, $1 \mathrm{H} ; \mathrm{CH}=\mathrm{CH}$ ), $5.01\left(\mathrm{~d}, J=7.2 \mathrm{~Hz}, 1 \mathrm{H}^{\prime} \mathrm{H}^{1}\right.$ ), 4.75 (dd, J=4.8, $\left.12.8 \mathrm{~Hz}, 1 \mathrm{H} ; \mathrm{H}^{2}\right), 4.72\left(\mathrm{~d}, \mathrm{~J}=6.8 \mathrm{~Hz}, 1 \mathrm{H} ; \mathrm{H}^{5}\right), 3.60$ (dd, J=5.0, $\left.10.4 \mathrm{~Hz}, 1 \mathrm{H} ; \mathrm{CH}_{2} \mathrm{OSi}\right), 3.36$ (dd, J=8.6, 10.6, $1 \mathrm{H} ; \mathrm{CH}_{2} \mathrm{OSi}$ ), 2.50-2.38 (m, $\left.1 \mathrm{H} ; \mathrm{H}^{4}\right), 1.78\left(\mathrm{q}, \mathrm{J}=12.7 \mathrm{~Hz}, 1 \mathrm{H}^{2} \mathrm{H}^{3^{\prime}}\right), 1.47(\mathrm{td}, J=4.8$, 
$\left.12.8 \mathrm{~Hz}, 1 \mathrm{H} ; \mathrm{H}^{3}\right), 1.07 \mathrm{ppm}(\mathrm{s}, 9 \mathrm{H} ; t \mathrm{Bu}) ;{ }^{13} \mathrm{C} \mathrm{NMR}\left(100 \mathrm{MHz} \mathrm{CDCl}_{3}\right)$ : $\delta=167.7,135.7,134.4,133.3,131.9,130.0,129.4,128.0,125.0$, $123.5,80.0,78.6,65.0,52.4,44.5,27.0,26.3,19.4$ ppm. HRMS (ESI): $\mathrm{m} / \mathrm{z}$ calcd for $\mathrm{C}_{32} \mathrm{H}_{33} \mathrm{NO}_{5} \mathrm{Si}+\mathrm{Na}^{+}: 562.2020\left[\mathrm{M}+\mathrm{Na}^{+}\right]$; found: 562.2010.

\section{S-(tert-Butyldiphenylsilyloxy)methyl-2S-phthalimido-8,9-} dioxabicyclo-[3.2.2]non-6-ene $((+)-18)$ : Protection of $(+)-17$ (200 mg, $0.664 \mathrm{mmol}$ ) with tert-butyldiphenylsilyl chloride was carried out in a similar fashion to the reaction of $( \pm)-\mathbf{1 7}$ to afford $(+)$-18 (311 mg, $87 \%$ ). M.p. $44-47^{\circ} \mathrm{C} ;[\alpha]_{\mathrm{D}}^{20}=+48(c=0.0013$ in $\mathrm{CH} 2 \mathrm{Cl} 2)$. The NMR spectral data for $(+) \mathbf{- 1 8}$ was identical to that for the racemic compound $( \pm) \mathbf{- 1 8}$.

\section{R-(tert-Butyldiphenylsilyloxy)methyl-2S-phthalimido-8,9-} dioxabicyclo-[3.2.2]non-6-ene ((-)-18): Protection of $(-)-17$ (200 mg, $0.664 \mathrm{mmol}$ ) with tert-butyldiphenylsilyl chloride was carried out in a fashion similar to the reaction of $( \pm)-\mathbf{1 7}$, except that the reaction time was extended to $15 \mathrm{~h}$, to afford (-)-18 (358 $\mathrm{mg}, 99 \%$ ). M.p. $45-47^{\circ} \mathrm{C} ;[\alpha]_{\mathrm{D}}^{20}=-48(c=0.0012$ in $\mathrm{CH} 2 \mathrm{Cl} 2)$. The NMR spectral data for $(-) \mathbf{- 1 8}$ was identical to that for the racemic compound $( \pm)-$ 18.

\section{6-(tert-Butyldiphenylsilyloxy)methyl-3,7-dihydroxy-4-} phthalimido-cycloheptene (( $\mathbf{( 1 )}-\mathbf{1 9})$ : Activated zinc dust (55 mg) was added to a solution of $( \pm)-\mathbf{1 8}(55.0 \mathrm{mg}, 0.102 \mathrm{mmol})$ in $\mathrm{CH}_{2} \mathrm{Cl}_{2}$ (5 $\mathrm{mL}$ ). Acetic acid $\left(61 \mathrm{mg}, 1.020 \mathrm{mmol}\right.$ ) dissolved in $\mathrm{CH}_{2} \mathrm{Cl}_{2}(3 \mathrm{~mL})$ was added dropwise over a $10 \mathrm{~min}$ period to this suspension. The reaction mixture was stirred for $15 \mathrm{~min}$ at room temperature, the solvent was evaporated, and the residue was purified by column chromatography $\left(\mathrm{SiO}_{2}\right.$, hexanes/ethyl acetate 2:3) to afford ( \pm )-19 (52 $\left.\mathrm{mg}, 94 \%\right)$ as a colorless foam. M.p. $51-53^{\circ} \mathrm{C} ;{ }^{1} \mathrm{H}$ NMR $\left(400 \mathrm{MHz}, \mathrm{CDCl}_{3}\right): \delta=7.85-$ 7.63 (m, 8H; Phth, Ar-H), 7.45-7.34 (m, 6H; Ar-H), 5.80 (td, J=2.8, $12.8 \mathrm{~Hz}, 1 \mathrm{H} ; \mathrm{CH}=\mathrm{CH}), 5.68(\mathrm{td}, J=2.6,12.8 \mathrm{~Hz}, 1 \mathrm{H} ; \mathrm{CH}=\mathrm{CH}), 4.93-$ $4.87\left(\mathrm{~m}, 1 \mathrm{H} ; \mathrm{H}^{3}\right), 4.45$ (br d, $\left.J=9.6 \mathrm{~Hz}, 1 \mathrm{H} ; \mathrm{H}^{7}\right), 4.14$ (ddd, J=2.4, $\left.10.0,12.4 \mathrm{~Hz}, 1 \mathrm{H} ; \mathrm{H}^{4}\right), 4.07(\mathrm{~d}, J=2.4 \mathrm{~Hz}, 1 \mathrm{H} ; \mathrm{OH}) .3 .75$ (dd, J=4.0, $10.2 \mathrm{~Hz}, 1 \mathrm{H} ; \mathrm{CH}_{2} \mathrm{OSi}$ ), 3.69 (dd, J=7.2, $10.2 \mathrm{~Hz}, 1 \mathrm{H} ; \mathrm{CH}_{2} \mathrm{OSi}$ ), 2.38 (td, $\left.J=12.0,14.8 \mathrm{~Hz}, 1 \mathrm{H} ; \mathrm{H}^{5^{\prime}}\right), 2.00-1.90\left(\mathrm{brm}, 1 \mathrm{H} ; \mathrm{H}^{6}\right), 1.87(\mathrm{~d}$, $J=6.8 \mathrm{~Hz}, 1 \mathrm{H} ; \mathrm{OH}), 1.56\left(\mathrm{td}, J=2.4,14.4 \mathrm{~Hz}, 1 \mathrm{H} ; \mathrm{H}^{5}\right), 1.07 \mathrm{ppm}(\mathrm{s}$, 
$9 \mathrm{H} ; t \mathrm{Bu}) ;{ }^{13} \mathrm{C}$ NMR $\left(100 \mathrm{MHz} \mathrm{CDCl}_{3}\right): \delta=168.7,136.3,135.8,135.7$, $134.2,132.7,132.07,132.02,130.23,130.17,128.11,128.06$, $123.4,74.1,70.2,68.7,55.0,44.8,33.1,27.0,19.3$ ppm; elemental analysis calcd (\%) for $\mathrm{C}_{32} \mathrm{H}_{35} \mathrm{NO}_{5} \mathrm{Si}$ : C 70.95, $\mathrm{H} 6.51$; found: $\mathrm{C} 70.66$, H6.60.

\section{S-(tert-Butyldiphenylsilyloxy)methyl-3S,7R-dihydroxy-4S-} phthalimidocycloheptene $((+)-19)$ : The reduction of endoperoxide $(+) \mathbf{- 1 8}$ (80 $\mathrm{mg}, 0.15 \mathrm{mmol}$ ) with $\mathrm{Zn}$ and acetic acid was carried out in a similar fashion to the reduction of the racemic endoperoxide $( \pm)-\mathbf{1 8}$ to afford $(+)-19(73 \mathrm{mg}, 91 \%)$. M.p. $53-55^{\circ} \mathrm{C} ;[\alpha]_{\mathrm{D}}^{20}=+17(c=0.0011$ in $\mathrm{CH}_{2} \mathrm{Cl}_{2}$ ). The NMR spectral data for $(+) \mathbf{- 1 9}$ was identical to that for the racemic compound $( \pm) \mathbf{- 1 9}$.

\section{R-(tert-Butyldiphenylsilyloxy)methyl-3R,7S-dihydroxy-4S-} phthalimidocycloheptene $(\mathbf{(} \pm \mathbf{)}-\mathbf{1 9})$ : The reduction of endoperoxide $(-)-18$ (80 $\mathrm{mg}, 0.15 \mathrm{mmol}$ ) with $\mathrm{Zn}$ and acetic acid was carried out in a similar fashion to the reduction of the racemic endoperoxide $( \pm)-18$ to afford (-)-19 (80 mg, 91\%). M.p. $57-59^{\circ} \mathrm{C} ;[\alpha]_{\mathrm{D}}^{20}=-11(c=0.00062$ in $\mathrm{CH}_{2} \mathrm{Cl}_{2}$ ). The NMR spectral data for $(-)-19$ was identical to that for the racemic compound $( \pm)-19$.

\section{6-(tert-Butyldiphenylsilyloxy)methyl-2,3,4,5-tetrahydroxy-1- phthalimidocycloheptane $(( \pm)-20)$ : A solution of $N$ -} methylmorpholine $\mathrm{N}$-oxide $(14 \mathrm{mg}, 0.122 \mathrm{mmol})$ in water $(1 \mathrm{~mL})$ was added to a solution of $( \pm)-\mathbf{1 9}(44 \mathrm{mg}, 0.081 \mathrm{mmol})$ in acetone $(5 \mathrm{~mL})$, followed by the addition of a solution of $\mathrm{OsO}_{4}(0.05 \mathrm{~mL}, 0.2 \mathrm{M}$ in toluene, $0.01 \mathrm{~mol})$. The reaction mixture was stirred for $2 \mathrm{~h}$ at room temperature under $\mathrm{N}_{2}$. The solvent was evaporated and the residue was purified by column chromatography $\left(\mathrm{SiO}_{2}\right.$, hexanes/ethyl acetate $1: 4)$ to afford $( \pm)-\mathbf{2 0}(41 \mathrm{mg}, \mathbf{8 8} \%)$ as a colorless foam. M.p. 86$87^{\circ} \mathrm{C} ;{ }^{1} \mathrm{H}$ NMR (400 MHz, $\left.\mathrm{CD}_{3} \mathrm{OD}\right): \delta=7.90-7.78$ (m, 4H; Phth), 7.65$7.55(\mathrm{~m}, 4 \mathrm{H} ; \mathrm{Ar}-\mathrm{H}), 7.35-7.22(\mathrm{~m}, 6 \mathrm{H} ; \mathrm{Ar}-\mathrm{H}), 4.50(\mathrm{dd}, \mathrm{J}=7.0,10.2$ $\left.\mathrm{Hz}, 1 \mathrm{H} ; \mathrm{H}^{2}\right), 4.11\left(\mathrm{dt}, J=1.6,11.0 \mathrm{~Hz}, 1 \mathrm{H} ; \mathrm{H}^{1}\right), 3.97(\mathrm{~d}, J=4.8 \mathrm{~Hz}, 1 \mathrm{H}$; $\left.\mathrm{H}^{4}\right), 3.89\left(\mathrm{dd}, \mathrm{J}=4.2,9.8 \mathrm{~Hz}, 1 \mathrm{H} ; \mathrm{H}^{5}\right), 3.83\left(\mathrm{~d}, \mathrm{~J}=6.8 \mathrm{~Hz}, 1 \mathrm{H} ; \mathrm{H}^{3}\right)$, 3.68-3.58 (m, 2H; $\left.\mathrm{H}^{8}, \mathrm{H}^{8^{\prime}}\right), 2.60\left(\mathrm{td}, J=11.2,14.4 \mathrm{~Hz}, 1 \mathrm{H}^{\prime} \mathrm{H}^{7}\right), 1.76-$ $1.67\left(\mathrm{~m}, 1 \mathrm{H} ; \mathrm{H}^{6}\right), 1.55\left(\mathrm{~d}, J=14.0 \mathrm{~Hz}, 1 \mathrm{H} ; \mathrm{H}^{7^{\prime}}\right) ; 0.99 \mathrm{ppm}(\mathrm{s}, 9 \mathrm{H}$; tBu $) ;{ }^{13} \mathrm{C} \mathrm{NMR}\left(100 \mathrm{MHz}, \mathrm{CD}_{3} \mathrm{OD}\right): \delta=169.8,136.9,136.8,135.4$, $133.5,130.93,130.88,128.88,128.84,124.2,78.5,75.8,73.6,72.1$, 
67.9, 58.5, 29.4, 27.5, $20.2 \mathrm{ppm}$; HRMS (ESI): $\mathrm{m} / \mathrm{z}$ calcd for $\mathrm{C}_{32} \mathrm{H}_{37} \mathrm{NO}_{7} \mathrm{Si}+\mathrm{Na}^{+}: 598.2232\left[\mathrm{M}+\mathrm{Na}^{+}\right]$; found: 598.2219 .

6S-(tert-Butyldiphenylsilyloxy)methyl-2R,3S,4R,5Stetrahydroxy-1Sphthalimido-cycloheptane (-)-20: The dihydroxylation of $(+) \mathbf{- 1 9}\left(65 \mathrm{mg}, 0.12 \mathrm{mmol}\right.$ ) with catalytic $\mathrm{OsO}_{4}$ was carried out in a fashion to the dihydroxylation of $( \pm) \mathbf{- 1 9}$, to afford ()-20 (61 mg, 88\%). M.p. $86-88^{\circ} \mathrm{C} ;[\alpha]_{\mathrm{D}}^{20}=-17(c=0.0010$ in $\mathrm{MeOH})$. The NMR spectral data for $(-) \mathbf{- 2 0}$ was identical to that for the racemic compound $( \pm)-\mathbf{2 0}$.

\section{R-(tert-Butyldiphenylsilyloxy)methyl-2S,3R,4S,5R-} tetrahydroxy-1Rphthalimido-cycloheptane $((+)-20)$ : The dihydroxylation of (-)-19 (75 mg, $0.138 \mathrm{mmol}$ ) with catalytic $\mathrm{OsO}_{4}$ was carried out in a similar fashion to the dihydroxylation of $( \pm)-\mathbf{1 9}$ to afford (+)-20 (70 mg, 88\%). M.p. $74-76^{\circ} \mathrm{C} ;[\alpha]_{\mathrm{D}}^{20}=+14(c=0.00090$ in $\mathrm{MeOH})$. The NMR spectral data for $(+)-\mathbf{2 0}$ was identical to that for the racemic compound $( \pm)-\mathbf{2 0}$.

\section{Acknowledgements}

This work was supported by the National Science Foundation (CHE-0848870) and NSF instrumentation grants (CHE-0521323). High-resolution mass spectra were obtained at the University of Nebraska-Center for Mass Spectrometry and the COSMIC lab at Old Dominion University.

[1] a) J. R. Medich, K. B. Kunnen, C. R. Johnson, Tetrahedron Lett. 1987, 28, 4131 - 4134;

[1] b) C. R. Johnson, T. D. Penning, J. Am. Chem. Soc. 1988, 110, 4726 4735;

[1] c) C. R. Johnson, M. P. Braun, H. Sundrum, Tetrahedron Lett. 1994, 35, $1833-1834$

[1] d) H. Sundram, A.Golebiowski, C. R. Johnson, Tetrahedron Lett. 1994, 35, 6975 - 6976;

[1] e) F. Li, J. B. Brogan, J. L. Gage, D. Zhang, M. J. Miller, J. Org. Chem. 1998, 63, 755 - 759;

[1] f) W. Lee, M. J. Miller, J. Org. Chem.2004, 69, 4516 -4519; permission has been granted for this version to appear in e-Publications@Marquette. Wiley-VCH Verlag does not grant permission for this article to be further copied/distributed or hosted elsewhere without the express permission from Wiley-VCH Verlag. 
[1] g) F. Li, N. C. Warshakoon, M. J. Miller, J. Org. Chem. 2004, 69, 8836 $8841 ;$

[1] h) F. Li, M. J. Miller, J. Org. Chem. 2006, 71, $5221-5227$.

[2] a) C. R. Johnson, A. Golebiowski, D. H. Steensma, J. Am. Chem. Soc. 1992, 114, $9414-9418$;

[2] b) C. R. Johnson, S. J. Bis, J. Org. Chem. 1995, 60, $615-623$;

[2] c) Y. Xu, C. R. Johnson, Tetrahedron Lett. 1997, 38, 1117 - 1120;

[2] d) T. Honda, N. Kimura, Org. Lett. 2002, 4, $4567-4570$.

[3] W. Reppe, O. Schichting, K. Klager, T. Toepel, Justus Liebigs Ann. Chem. 1948, 560, 1- 92.

[4] a) L. Kelebekli, M. Celik, E. Sahin, Y. Kara, M. Balci, Tetrahedron Lett. 2006, 47, 7031 - 7035;

[4] b) L. Kelebekli, Y. Kara, M. Balci, Carbohydr. Res. 2005, 340, 1940 1948;

[4] c) Y. Kara, M. Balci, Tetrahedron 2003, 59, 2063 -2066;

[4] d) V. Mascitti, E. J. Corey, J. Am. Chem. Soc. 2004, 126, 15664 - 15665;

[4] e) D. A. Evans, B. T. Connell, J. Am. Chem. Soc. 2003, 125, $10899-$ 10905; f) G. Metha, K. Pallavi, Chem. Commun. 2002, 2828 - 2829.

[5] Y. Shvo, E. Hazum, J. Chem. Soc. Chem. Commun. 1975, 829 -830.

[6] a) A. Davison, W. McFarlane, L. Pratt, G. Wilkinson, J. Chem. Soc. 1962, $4821-4829$;

[6] b) A. D. Charles, P. Diversi, B. F. G. Johnson, J. Lewis, J. Chem. Soc. Dalton Trans. 1981, 1906 - 1917; c) K. Broadley, N. G. Connelly, P. G. Graham, J. A. K. Howard, W. Risse, M. W. Whiteley, P. Woodward, J. Chem. Soc. Dalton Trans. 1985, 777 -781;

[6] d) K. Broadley, N. G. Connelly, R. Mills, M. W. Whiteley, P. Woodward, J. Chem. Soc. Dalton Trans. 1984, $683-688$.

[7] a) N. J. Wallock, W. A. Donaldson, J. Org. Chem. 2004, 69, 2997 - 3007;

[7] b) S. Chaudhury, S. Lindeman, W. A. Donaldson, Tetrahedron Lett. 2007, $48,7849-7852$.

[8] a) S. Wacharasindhu, W. Worawalai, W. Rungprom, P. Phuwapraisirisan, Tetrahedron Lett. 2009, 50, 2189 -2192;

[8] b) V. R. Doddi, A. Kumar, Y. D. Vankar, Tetrahedron 2008, 64, 9117 9122;

[8] c) C. Bauder, Org. Biomol. Chem. 2008, 6, 2952 - 2960;

[8] d) C. Alegret, J. Benet-Buchholz, A. Riera, Org. Lett. 2006, 8, 3069 3072;

[8] e) S. Ogawa, M. Asada, Y. Ooki, M. Mori, M. Itoh, T. Korenaga, Bioorg. Med. Chem. 2005, 13, $4306-4314$;

[8] f) J. Yu, J. B. Spencer, Tetrahedron Lett. 2001, 42, 4219 -4221;

[8] g) I. F. Pelyv_s, M. Madi-Puskas, Z. G. T_th, Z. Varga, G. Batta, F. Saztaricskai, Carbohydr. Res. 1995, 272, C5-C9;

Chemistry, a European Journal, Vol. 19, No. 4 (February 2013): pg. 2330-2336. DOI. This article is (C) Wiley-VCH Verlag and permission has been granted for this version to appear in e-Publications@Marquette. Wiley-VCH Verlag does not grant permission for this article to be further copied/distributed or hosted elsewhere without the express permission from Wiley-VCH Verlag. 
[8] h) J. Marco-Contelles, C. Pozuelo, M. L. Jimeno, L. Martinez, A. MartinezGrau, J. Org. Chem. 1992, 57, 2625 - 2631.

[9] a) G. Rassu, L. Auzzas, L. Pinna, V. Zambrano, F. Zanardi, L. Battistini, E. Gaetani, C. Curti, G. Casiraghi, J. Org. Chem. 2003, 68, 5881 - 5885;

[9] b) C. Curti, F. Zanardi, L. Battistini, A. Sartori, G. Rassu, L. Auzzas, A. Roggio, L. Pinna, G. Casiraghi, J. Org. Chem. 2006, 71, 225 -230;

[9] c) T. K. M. Shing, W. F. Wong, T. Ikeno, T. Yamada, Org. Lett. 2007, 9, $207-209$;

[9] d) E. Girard, V. Desvergnes, C. Tarnus, Y. Landais, Org. Biomol. Chem. $2010,8,5628$ - 5634;

[9] e) R. Beniazza, V. Desvergnes, G. Mehta, N. Blanchard, F. Robert, Y. Landais, J. Org. Chem. 2011, 76, $791-799$.

[10] I. Kuwajima, K. Tanino, Chem. Rev. 2005, 105, $4661-4670$.

[11] a) B. F. G. Johnson, J. Lewis, P. McArdle, G. L. P. Randall, J. Chem. Dalton Trans. 1972, $456-462$;

[11] b) A. J. Pearson, S. L. Kole, B. Chen, J. Am. Chem. Soc. 1983, 105, 4483 -4484 ;

[11] c) A. J. Pearson, S. L. Kole, T. Ray, J. Am. Chem. Soc. 1984, 106, 6060 -6074 ;

[11] d) A. J. Pearson, M. P. Burello, Organometallics 1992, 11, 448 - 456;

[11] e) M.-C. P. Yeh, C.-C. Hwu, C.-H. Ueng, H.-L. Lue, Organometallics $1994,13,1788-1794$.

[12] CCDC-902709 (( \pm )-9d) contains the supplementary crystallographic data for this paper. These data can be obtained free of charge from The Cambridge Crystallographic Data Centre via www.ccdc.cam.ac.uk/data_request/cif.

[13] Preliminary communication: M. F. El-Mansy, A. Sar, S. Chaudhury, N. J. Wallock, W. A. Donaldson, Org. Biomol. Chem. 2012, 10, $4844-4846$.

[14] a) M. B. Dinger, J. C. Mol, Organometallics 2003, 22, 1089 -1095;

[14] b) S. H. Hong, D. P. Sanders, C. W. Lee, R. H. Grubbs, J. Am. Chem. Soc. 2005, 127, $17160-17161$;

[14] c) F. C. Courchay, J. C. Sworen, I. Ghiviriga, K. A. Abboud, K. B. Wagener, Organometallics 2006, 25, 6074 - 6086.

[15] a) A. J. Pearson, H. S. Bansal, Y. S. Lai, J. Chem. Soc. Chem. Commun. $1987,519-520$;

[15] b) P. Imming, G. Seitz, Chem. Ber. 1989, 122, 2183 -2185.

[16] a) J. K. Cha, W. J. Christ, Y. Kishi, Tetrahedron Lett. 1983, 24, 3943 3946;

[16] b) W. J. Christ, J. K. Cha, Y. Kishi, Tetrahedron Lett. 1983, 24, 3947 3950;

[16] c) J. K. Cha, W. J. Christ, Y. Kishi, Tetrahedron 1984, 40, 2247 - 2255.

[17] H. C. Kolb, M. S. VanNieuwenhze, K. B. Sharpless, Chem. Rev. 1994, 94, $2483-2547$.

Chemistry, a European Journal, Vol. 19, No. 4 (February 2013): pg. 2330-2336. DOI. This article is (C) Wiley-VCH Verlag and permission has been granted for this version to appear in e-Publications@Marquette. Wiley-VCH Verlag does not grant permission for this article to be further copied/distributed or hosted elsewhere without the express permission from Wiley-VCH Verlag. 
NOT THE PUBLISHED VERSION; this is the author's final, peer-reviewed manuscript. The published version may be accessed by following the link in the citation at the bottom of the page.

[18] CCDC-902710 ((+)-26·C4H8O2) contains the supplementary crystallographic data for this paper. These data can be obtained free of charge from The Cambridge Crystallographic Data Centre via www.ccdc.cam.ac.uk/data_request/cif.

[19] J. A. Dale, H. S. Mosher, J. Am. Chem. Soc. 1973, 95, 512 -519.

Notes: [a] M. F. El-Mansy, Dr. A. Sar, Dr. S. Lindeman, Dr. W. A. Donaldson, Department of Chemistry, Marquette University, P.O. Box 1881, Milwaukee, Wisconsin 53201-1881 (USA)

Fax: (+1) 414-288-7066

E-mail: william.donaldson@marquette.edu

Supporting information for this article is available on the WWW under http://dx.doi.org/10.1002/chem.201203754. 